Supporting information to accompany

\title{
Synthesis of RNA using 2'-O-DTM protection
}

Andrey Semenyuk, Andras Földesi, Tommy Johansson, Camilla Estmer, Peter Blomgren, Mathias Brännvall, Leif A. Kirsebom and Marek Kwiatkowski*.

\section{Contents}

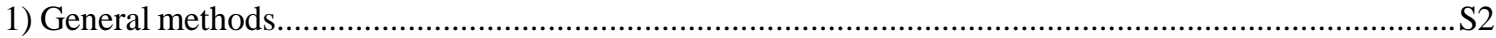

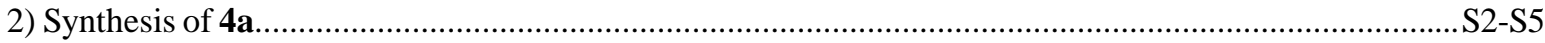

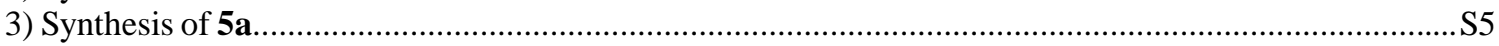

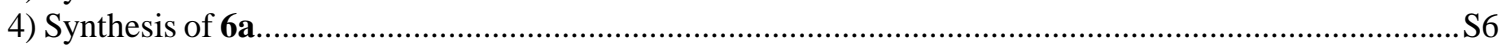

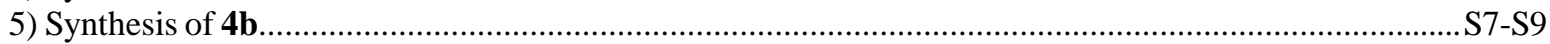

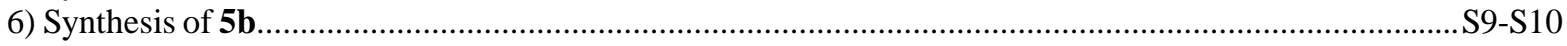

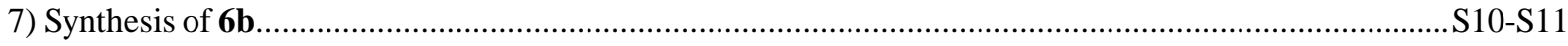

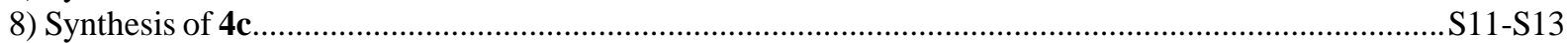

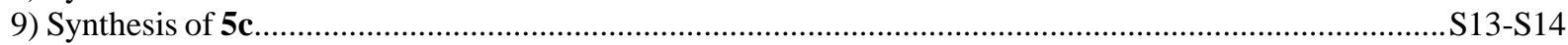

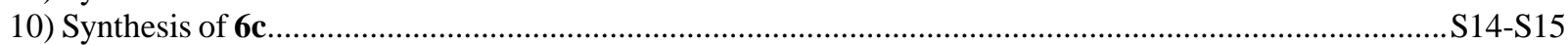

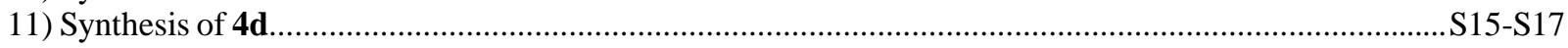

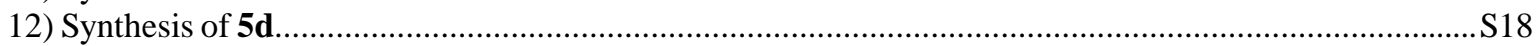

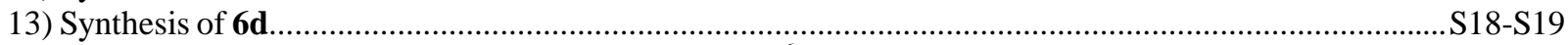

14) Supporting Information Scheme 1. Synthesis of $O^{6}$-DPC protected guanosine phosphoramidite

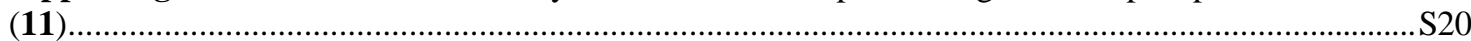

15) Synthesis of 10

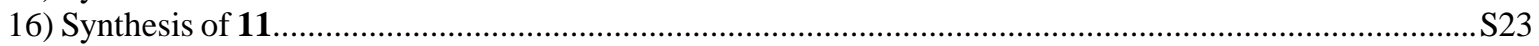

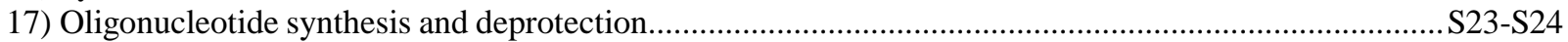

18) RNase P RNA mediated cleavage of a model substrate, pATSerUG....................................................S24

19) RNase H mediated cleavage of a 22-mer RNA-DNA duplex.............................................................S24-S25

20) Supporting Information Figure 1. Purity of 2'-O-DTM-uridine (4d) ........................................S26

21) Supporting Information Figure 2. Stability of 2'-O-DTM amidites 6a-d and $\mathbf{1 1}$ in specified

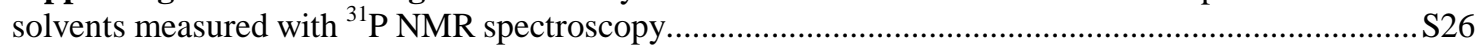

22) Supporting Information Scheme 2. Two step deprotection of a $2^{\prime}$ - $O$-DTM group..............................S27

23) Supporting Information Table 1. Deprotection of 2'-O-DTM-adenosilyl-(5' $\rightarrow 3$ ')-cytidine $(0.1 \mathrm{mM}$

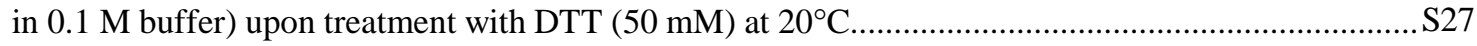

24) Supporting Information Table 2. Deprotection of 2'- $O$-DTM-adenosilyl- $\left(5^{\prime} \rightarrow 3^{\prime}\right)$-cytidine $(0.1 \mathrm{mM}$ in $0.1 \mathrm{M}$ buffer $)$ upon treatment with TCEP $(50 \mathrm{mM})$ at $20^{\circ} \mathrm{C}$

25) Supporting Information Table 3. Deprotection conditions for removal of 2'-O-DTM groups from oligoribonucleotides $(0.1 \mathrm{mM})$ of different lengths (in $0.2 \mathrm{M}$ phosphate buffer)......

26) Supporting Information Figure 3. Deprotection rates of RNA dimers $(0.1 \mathrm{mM}$ in $0.2 \mathrm{M}$ phosphate buffer), having different 2'-O-DTM-protected nucleosides on their 5'-termini, upon treatment with DTT $(50 \mathrm{mM})$......

27) Supporting Information Figure 4. Nuclease P1 and alkaline phosphatase mediated hydrolysis of

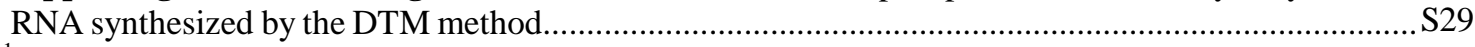

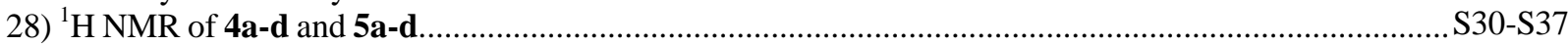

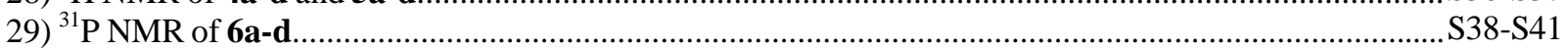

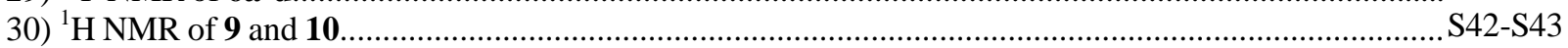

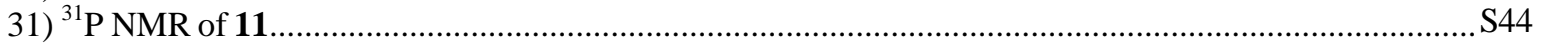


General Methods. All reagents and solvents were obtained from commercial sources and used without purification. 5-Ethylthio-1- $H$-tetrazole (ETT) was obtained from ChemGenes Corporation. TLC: pre-coated silica gel plates Kieselgel 60 F254 were obtained from Merck and used with following systems: (System I) chloroform - methanol, 9:1(v/v); (System II), chloroform - methanol 19:1 (v/v), (System III) hexane - ethyl acetate - triethylamine 6:3:1 (v/v/v). Flush chromatography: silica gel 60 (230-400 mesh) from SDS (France). Reversed-

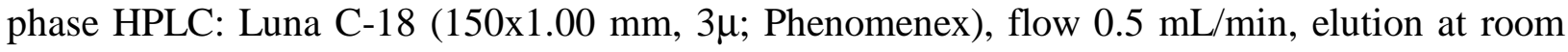
temperature; eluent $\mathrm{A}-5 \%$ acetonitrile in $0.1 \mathrm{M}$ TEAA (pH 7), eluent $\mathrm{B}-80 \%$ acetonitrile in 0.1 M TEAA (pH 7).

High-resolution FAB-MS analyses were performed in the positive-ion mode with a JMSSX/SX102A mass spectrometer (JEOL, Japan) operated at a $10 \mathrm{kV}$ accelerating potential, and ions were produced by bombardment with $\mathrm{Xe}$ atoms of $6 \mathrm{keV}$ energy. Glycerol was used as the matrix, except for the analyses of amidites, where it was replaced by 3-nitrobenzyl alcohol. Polyethylene glycol was used to obtain reference standard peaks.

\section{$N^{6}$-Benzoyl-2'-O-(tert-butyldithiomethyl)adenosine (4a).}

\section{Step 1: $N^{6}$-benzoyl-3',5'-O-(1,1,3,3-tetraisopropyldisiloxane-1,3-} diyl)adenosine. $N^{6}$-Benzoyladenosine (1a) $(16.71 \mathrm{~g}, 45 \mathrm{mmol}, 1$ eq. $)$ was dried by co-evaporation with anhydrous pyridine $(3 \times 200 \mathrm{~mL})$.

The residue was re-dissolved in anhydrous pyridine $(250 \mathrm{~mL})$ and

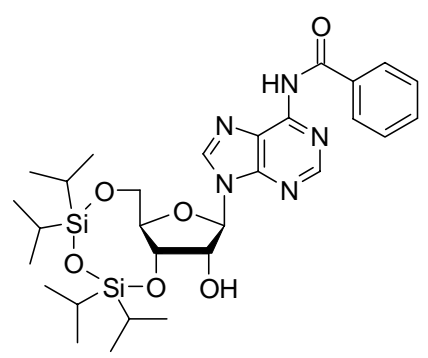
1,3-dichloro-1,1,3,3-tetraisopropyldisiloxane $(17.28 \mathrm{~mL}, 54 \mathrm{mmol}$, 1.2 eq.) was added dropwise within $30 \mathrm{~min}$. The reaction mixture was stirred at room temperature until complete conversion of the starting material ( 3 hours), which was monitored by TLC 
(System I). The reaction mixture was poured slowly into saturated aqueous sodium bicarbonate solution $(500 \mathrm{~mL})$ and extracted with dichloromethane $(3 \times 200 \mathrm{~mL})$. The combined organic layers were dried over $\mathrm{MgSO}_{4}$, filtered, concentrated to syrup and co-evaporated with toluene (3x200 $\mathrm{mL})$. The crude $N^{6}$-benzoyl-3',5'-O-(1,1,3,3-tetraisopropyldisiloxane-1,3-diyl)-adenosine (29.7 g) was obtained as a foam and used without purification.

\section{Step 2: $N^{6}$-benzoyl-3',5'-O-(1,1,3,3-tetraisopropyldisiloxane-1,3-} diyl)-2'-O-[(methylthio)methyl]adenosine (2a) To the solution of obtained crude $N^{6}$-benzoyl-3',5'-O-(1,1,3,3-tetraisopropyldisiloxane1,3-diyl)adenosine in DMSO (68 $\mathrm{mL})$ acetic acid $(68 \mathrm{~mL})$ and acetic anhydride $(45 \mathrm{~mL})$ were added. The reaction mixture was stirred at

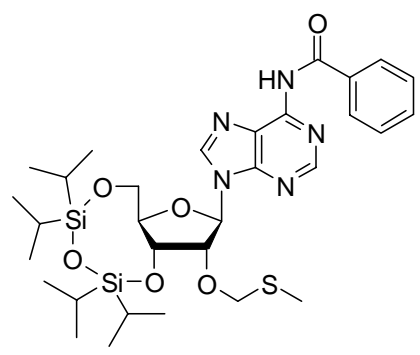
room temperature until completion (48 hours), which was monitored by TLC (System II). Then the reaction mixture was transferred to a $2 \mathrm{~L}$ E-flask. Potassium carbonate (140 g) was dissolved in water $(700 \mathrm{~mL})$ and the resulting solution was added slowly to the reaction mixture under vigorous stirring. The precipitated product was filtered, re-dissolved in a small volume of THF and precipitated again from water $(700 \mathrm{~mL})$. The obtained residue was dissolved and coevaporated with pyridine $(1 \times 200 \mathrm{~mL})$, toluene $(3 \times 200 \mathrm{~mL})$ and finally dichloromethane $(1 \times 200$ $\mathrm{mL})$. The resulting crude $N^{6}$-benzoyl-3',5'-O-(1,1,3,3-tetraisopropyldisiloxane-1,3-diyl)-2'-O[(methylthio)methyl]adenosine (2a) (30.4 g) was used in the next step without further purification. A portion of the compound $(100 \mathrm{mg})$ was purified for the analysis. ${ }^{1} \mathrm{H}-\mathrm{NMR}$ (270 $\mathrm{MHz}, \mathrm{CDCl}_{3}$ ): $\delta 9.10$ (br. s); 8.74 (s, 1H); 8.29 (s, 1H); 8.00 (br. d, 2H); 7.61-7.46 (m, 3H); 6.09 $(\mathrm{s}, 1 \mathrm{H}) ; 5.05 \& 4.98(2 \mathrm{xd}, \mathrm{J}=11.5 \mathrm{~Hz}, 2 \mathrm{H}) ; 4.72-4.64(\mathrm{~m}, 2 \mathrm{H}) ; 4.24($ br. d, J = 13.5 Hz, 1H); 4.18-4.14 (m, 1H); $4.01(\mathrm{dd}, \mathrm{J}=13.4 \mathrm{~Hz}, \mathrm{~J}=2.5 \mathrm{~Hz}, 1 \mathrm{H}) ; 2.18(\mathrm{~s}, 3 \mathrm{H}) ; 1.08-0.95(\mathrm{~m}, 28 \mathrm{H})$. 
Step 3: Crude $N^{6}$-benzoyl-3',5'-O-(1,1,3,3-tetraisopropyldisiloxane-1,3diyl)-2'-O-[(methylthio)methyl]adenosine (2a) (30.3 g) obtained from the previous step was dissolved in anhydrous dichloromethane $(200 \mathrm{~mL})$ containing triethylamine $(6.27 \mathrm{~mL}, 45 \mathrm{mmol}, 1.0$ eq.), followed by

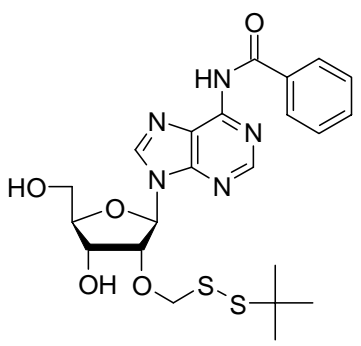
addition of molecular sieves $(3 \AA, 22 \mathrm{~mL})$. The mixture was stirred at room temperature for 30 minutes and then cooled in an ice-bath. A solution of sulfuryl chloride $(3.62 \mathrm{~mL}, 45 \mathrm{mmol}, 1$ eq.) in anhydrous dichloromethane $(25 \mathrm{~mL})$ was added dropwise to the reaction mixture during 30 minutes. The ice-bath was removed and the reaction mixture was stirred further for 30 minutes followed by addition of potassium thiotosylate $(15.28 \mathrm{~g}, 67.5 \mathrm{mmol}, 1.5 \mathrm{eq}$.$) in anhydrous DMF$ $(30 \mathrm{~mL})$. Stirring was continued at room temperature for additional 30 minutes followed by addition of tert-butyl mercaptan $(9.64 \mathrm{~mL}, 90 \mathrm{mmol}, 2$ eq.). The reaction mixture was stirred at room temperature for 30 minutes and quickly filtered through a filter covered by celite $(\sim 2 \mathrm{~cm})$. The filter was washed with dichloromethane and the organic fraction was concentrated. The residue was suspended in methanol $(300 \mathrm{~mL})$ and ammonium fluoride $(6.67 \mathrm{~g}, 180 \mathrm{mmol}, 4 \mathrm{eq}$. was added. The reaction mixture was stirred at room temperature overnight ( $c a 16$ hours) until the complete cleavage of disiloxyl group (TLC - System I). The reaction mixture was concentrated in vacuo, saturated bicarbonate solution $(500 \mathrm{~mL})$ was added thereto and the mixture was extracted with dichloromethane $(3 \times 200 \mathrm{~mL})$. The organic layer was dried over $\mathrm{MgSO}_{4}$, filtered, concentrated and co-evaporated with toluene $(3 \times 200 \mathrm{~mL})$. The obtained crude mixture was purified by silica gel column chromatography using a gradient of dichloromethane methanol from 100:0 (v/v) to 94:6 (v/v). $N^{6}$-Benzoyl-2'-O-(tert-butyldithiomethyl)adenosine (4a) (10.33 g, $20.43 \mathrm{mmol})$ was isolated as a foam with $45 \%$ yield, calculated from 1a. ${ }^{1} \mathrm{H}-\mathrm{NMR}(270$ $\left.\mathrm{MHz}, \mathrm{CDCl}_{3}\right): \delta 9.16($ br. s, $1 \mathrm{H}) ; 8.81(\mathrm{~s}, 1 \mathrm{H}) ; 8.07(\mathrm{~s}, 1 \mathrm{H}) ; 8.05-8.02(\mathrm{~m}, 2 \mathrm{H}) ; 7.66-7.52(\mathrm{~m}$, 
$3 \mathrm{H}), 6.05(\mathrm{~d}, \mathrm{~J}=11.1 \mathrm{~Hz}, 1 \mathrm{H}) ; 6.00(\mathrm{~d}, \mathrm{~J}=7.6 \mathrm{~Hz}, 1 \mathrm{H}) ; 5.03(\mathrm{dd}, \mathrm{J}=7.4 \mathrm{~Hz}, \mathrm{~J}=4.6 \mathrm{~Hz}, 1 \mathrm{H})$; $4.79 \& 4.65(2 x d, J=11.3 \mathrm{~Hz}, 2 \mathrm{H}) ; 4.65(\mathrm{~d}, \mathrm{~J}=4.7 \mathrm{~Hz}, 1 \mathrm{H}) ; 4.39$ (br. s, 1H); 4.00 (br. d, J=12.9 $\mathrm{Hz}, 1 \mathrm{H}) ; 3.83-3.75(\mathrm{~m}, 1 \mathrm{H}) ; 1.24(\mathrm{~s}, 9 \mathrm{H})$; HRMS (FAB) calc for $\mathrm{C}_{22} \mathrm{H}_{27} \mathrm{~N}_{5} \mathrm{O}_{5} \mathrm{~S}_{2}\left(\mathrm{M}+\mathrm{H}^{+}\right)$ 506.1532, found 506.1525.

$N^{6}$-Benzoyl-5'-O-(4,4'-dimethoxytrityl)-2'-O-(tert-butyldithiomethyl)adenosine $\quad(5 \mathrm{a}) . \quad N^{6}-$ Benzoyl-2'-O-(tert-butyldithiomethyl)adenosine (4a) (10.33 g, 20.43 mmol, 1 eq.) was dissolved in anhydrous pyridine $(150 \mathrm{~mL})$, and 4,4'-dimethoxytrityl chloride (9.00 g, $26.56 \mathrm{mmol}, 1.2$ eq.) was added. The reaction mixture was stirred at room temperature until

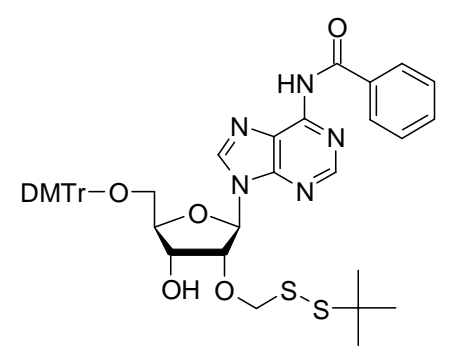
completion ( 2 hours), which was monitored by TLC (System II). The reaction mixture was poured into saturated sodium bicarbonate solution $(400 \mathrm{~mL})$ and extracted with dichloromethane $(3 \times 150 \mathrm{~mL})$. The combined organic layers were dried over $\mathrm{MgSO}_{4}$, filtered, concentrated and coevaporated with toluene $(3 \times 100 \mathrm{~mL})$. The obtained crude mixture was purified by silica gel column chromatography using a gradient of petroleum ether - ethyl acetate from 80:20 (v/v with addition of $0.2 \%$ TEA) to $0: 100(\mathrm{v} / \mathrm{v}) . N^{6}$-Benzoyl-5'-O-(4,4'-dimethoxytrityl)-2'-O-(tertbutyldithiomethyl)adenosine (5a) (14.97 $\mathrm{g}, 18.53 \mathrm{mmol})$ was isolated as a foam with $91 \%$ yield. ${ }^{1} \mathrm{H}-\mathrm{NMR}\left(270 \mathrm{MHz}, \mathrm{CDCl}_{3}+\mathrm{DABCO}\right): \delta 8.96$ (br. s, $\left.1 \mathrm{H}\right) ; 8.75$ (s, 1H); 8.24 (s, 1H); 8.04-8.01 $(\mathrm{m}, 2 \mathrm{H}) ; 7.65-7.19(\mathrm{~m}, 12 \mathrm{H}) ; 6.84-6.79(\mathrm{~m}, 4 \mathrm{H}) ; 6.25(\mathrm{~d}, \mathrm{~J}=5.1 \mathrm{~Hz}, 1 \mathrm{H}) ; 5.03 \& 4.88(2 \mathrm{xd}, \mathrm{J}=$ $11.3 \mathrm{~Hz}, 2 \mathrm{H}) ; 5.03(\mathrm{t}, \mathrm{J}=5.2 \mathrm{~Hz}, 1 \mathrm{H}) ; 4.62(\mathrm{dt}, \mathrm{J}=4.6 \mathrm{~Hz}, 1 \mathrm{H}) ; 4.31-4.27(\mathrm{~m}, 1 \mathrm{H}) ; 3.78(\mathrm{~s}, 6 \mathrm{H})$; $3.52(\mathrm{dd}, \mathrm{J}=10.6 \mathrm{~Hz}, \mathrm{~J}=3.2 \mathrm{~Hz}, 1 \mathrm{H}) ; 3.42(\mathrm{dd}, \mathrm{J}=10.6 \mathrm{~Hz}, \mathrm{~J}=3.8 \mathrm{~Hz}, 1 \mathrm{H}) ; 2.71(\mathrm{~d}, \mathrm{~J}=4.7 \mathrm{~Hz}$, $1 \mathrm{H}) ; 1.27$ (s, 9H). HRMS (FAB) calc for $\mathrm{C}_{43} \mathrm{H}_{46} \mathrm{~N}_{5} \mathrm{O}_{7} \mathrm{~S}_{2}\left(\mathrm{M}+\mathrm{H}^{+}\right)$808.2838, found 808.2757. 
$N^{6}$-Benzoyl-5'-O-(4,4'-dimethoxytrityl)-2'-O-(tert-butyldithiomethyl)adenosine $\quad 3$ '-O-(2cyanoethyl $N, N$-diisopropylphosphoramidite) (6a). $N^{6}$-Benzoyl-5'$O$-(4,4'-dimethoxytrityl)-2'-O-(tert-butyldithiomethyl)adenosine (5a) (9.63 g, 11.9 mmol, 1 eq.) was dissolved in anhydrous dichloromethane $(120 \mathrm{~mL})$ containing triethylamine $(8.31 \mathrm{~mL}, 59.6$

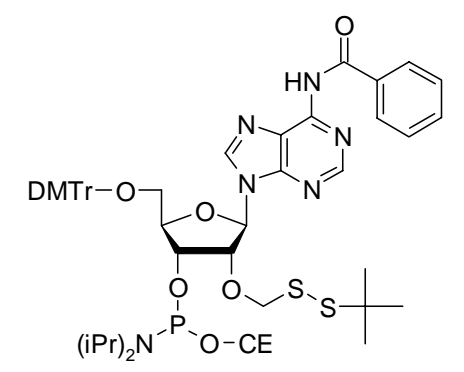
mmol, 5 eq.) followed by addition of 2-cyanoethyl $N, N$-diisopropylchlorophosphoramidite (4.52 $\mathrm{mL}, 20.26 \mathrm{mmol}, 1.7$ eq.). The reaction mixture was stirred at room temperature under argon until full conversion of the starting material (2 hours), which was monitored by TLC (System III). Then the reaction was quenched by stirring with methanol $(6 \mathrm{~mL})$ for 20 minutes. The reaction mixture was poured into saturated sodium bicarbonate solution $(180 \mathrm{~mL})$, and extracted with dichloromethane $(2 \times 100 \mathrm{~mL})$. The combined organic layers were dried over $\mathrm{MgSO}_{4}$, filtered and concentrated in vacuo. The obtained crude mixture was purified by silica gel column chromatography using a gradient of cyclohexane - ethyl acetate from 95:5 (v/v) to 10:90 (v/v) containing $3 \mathrm{~mL}$ triethylamine added per $100 \mathrm{~mL}$ of mobile phase. Collected fractions were evaporated and re-dissolved in dichloromethane $(30 \mathrm{~mL})$. A $1 \mathrm{~L} \mathrm{E-flask}$ was filled with hexane $(700 \mathrm{~mL})$ and placed into an ethanol bath at $-78^{\circ} \mathrm{C}$. The dichloromethane solution was added dropwise to the stirred hexane solution, and the amidite precipitated immediately as a white solid. The cold solid was filtered through a sintered filtration funnel and washed with cold hexane. The obtained residue was dissolved in dichloromethane and concentrated. $N^{6}$-Benzoyl-5'-O-(4,4'dimethoxytrityl)-2'-O-(tert-butyldithiomethyl)adenosine $\quad$ 3'-O-(2-cyanoethyl $\quad N, N$-diisopropylphosphoramidite) (6a) $(10.4 \mathrm{~g}, 10.3 \mathrm{mmol})$ was isolated as a white foam with $87 \%$ yield. ${ }^{31} \mathrm{P}$ NMR (CDCl 3 with DABCO): $151.60,150.81$ ppm; HRMS (FAB) calc for $\mathrm{C}_{52} \mathrm{H}_{63} \mathrm{~N}_{7} \mathrm{O}_{8} \mathrm{PS}_{2}(\mathrm{M}+$ $\mathrm{H}^{+}$) 1008.3917, found 1008.3973. 


\section{$N^{2}$-Isobutyryl-2'-O-(tert-butyldithiomethyl)guanosine (4b).}

\section{Step 1: $N^{2}$-isobutyryl-3',5'-O-(1,1,3,3-tetraisopropyldisiloxane-}

1,3-diyl)guanosine. $N^{2}$-Isobutyrylguanosine (1b) $(17.67 \mathrm{~g}, 50$

mmol, 1 eq.) was co-evaporated with anhydrous pyridine $(3 \times 250$

$\mathrm{mL})$. The residue was re-dissolved in anhydrous pyridine $(200 \mathrm{~mL})$

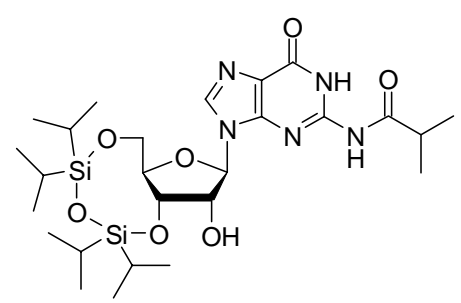
and 1,3-dichloro-1,1,3,3-tetraisopropyldisiloxane $(19.33 \mathrm{~mL}, 60 \mathrm{mmol}, 1.2 \mathrm{eq}$.$) was added. The$ reaction mixture was stirred at room temperature until completion (3.5 hours), which was monitored by TLC (System I). The reaction mixture was poured slowly into saturated aqueous sodium bicarbonate solution $(600 \mathrm{~mL})$ and extracted with dichloromethane $(3 \times 200 \mathrm{~mL})$. The combined organic layers were dried over $\mathrm{MgSO}_{4}$, filtered, concentrated to a syrup and coevaporated with toluene $(3 \times 250 \mathrm{~mL})$. The obtained crude $N^{2}$-isobutyryl-3',5'-O-(1,1,3,3tetraisopropyldisiloxane-1,3-diyl)guanosine was used in the next step without purification.

\section{Step 2: $N^{2}$-isobutyryl-3',5'-O-(1,1,3,3-tetraisopropyldisiloxane-} 1,3-diyl)-2'-O-[(methylthio)methyl]guanosine (2b). To the obtained crude $\quad N^{2}$-isobutyryl-3',5'-O-(1,1,3,3-tetraisopropyldisiloxane-1,3-diyl)guanosine in DMSO $(75 \mathrm{~mL})$ acetic acid $(75$ $\mathrm{mL})$ and acetic anhydride $(50 \mathrm{~mL})$ were added. The reaction

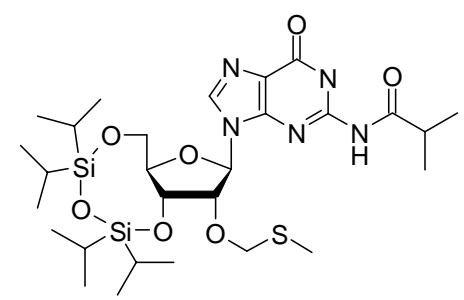
mixture was stirred at room temperature until completion $(24 \mathrm{~h})$, which was monitored by TLC (System I). Then the mixture was transferred to a $2 \mathrm{~L}$ E-flask. Potassium carbonate (170 g) was dissolved in water $(900 \mathrm{~mL})$ and the resulting solution was added slowly to the reaction mixture under vigorous stirring. The precipitated product was filtered, re-dissolved in a small volume of THF and precipitated again from water $(900 \mathrm{~mL})$. The obtained residue was dissolved and coevaporated with pyridine $(1 \times 250 \mathrm{~mL})$, toluene $(3 \times 250 \mathrm{~mL})$ and finally dichloromethane $(1 \times 250$ 
mL). $\quad N^{2}$-Isobutyryl-3', $5^{\prime}-O$-(1,1,3,3-tetraisopropyldisiloxane-1,3-diyl)-2'-O-[(methylthio)methyl]guanosine (2b) was obtained as a foam and was used in the next step without further purification. A portion of the compound (100 mg) was purified for the analysis. ${ }^{1} \mathrm{H}-\mathrm{NMR}(270$ MHz, $\mathrm{CDCl}_{3}$ ): $\delta 12.03$ (br. s, 1H); 8.58 (br. s, 1H); 8.01 (s, 1H) H8; 5.86 (s, 1H); $5.02 \& 4.95$ $(2 x d, J=11.5 \mathrm{~Hz}, 2 \mathrm{H}) ; 4.52-4.46(\mathrm{~m}, 2 \mathrm{H}) ; 4.24(\mathrm{~d}, \mathrm{~J}=13.4 \mathrm{~Hz}, 1 \mathrm{H}) ; 4.16-4.11(\mathrm{~m}, 1 \mathrm{H}) ; 4.01$ $(\mathrm{dd}, \mathrm{J}=13.3 \mathrm{~Hz}, \mathrm{~J}=2.4 \mathrm{~Hz}, 1 \mathrm{H}) ; 2.68(\mathrm{se}, \mathrm{J}=6.9 \mathrm{~Hz}, 1 \mathrm{H}) ; 2.17(\mathrm{~s}, 3 \mathrm{H}) ; 1.27 \& 1.26(2 \mathrm{xd}, \mathrm{J}=$ $6.9 \mathrm{~Hz}, 6 \mathrm{H}) ; 1.10-0.95(\mathrm{~m}, 28 \mathrm{H})$.

Step 3: crude $N^{2}$-isobutyryl-3',5'-O-(1,1,3,3-tetraisopropyl-disiloxane1,3-diyl)-2'-O-[(methylthio)methyl]guanosine (2b) obtained from the previous step was dissolved in anhydrous dichloromethane $(250 \mathrm{~mL})$, and molecular sieves were added $(3 \AA, 10 \mathrm{~mL})$. The reaction mixture

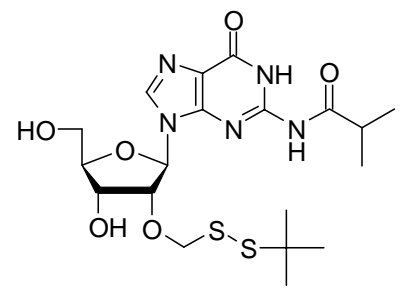
was stirred at room temperature for $30 \mathrm{~min}$ and then cooled with an ice-bath. A solution of sulfuryl chloride (3.82 mL, $47.5 \mathrm{mmol}, 0.95$ eq.) in anhydrous dichloromethane (90 mL) was added dropwise to the reaction mixture within 20 minutes followed by addition of cyclohexene $(10.13 \mathrm{~mL}, 100 \mathrm{mmol}, 2$ eq.). Then the ice-bath was removed and the reaction mixture was stirred for additional 30 minutes. A solution of potassium thiotosylate $(16.98 \mathrm{~g}, 75 \mathrm{mmol}, 1.5 \mathrm{eq}$.) in dry DMF (34 mL) was added to the reaction mixture followed by stirring at room temperature for 30 minutes. Then tert-butyl mercaptan $(10.71 \mathrm{~mL}, 100 \mathrm{mmol}, 2$ eq.) was added thereto and stirring was continued at room temperature for additional 30 minutes. The reaction mixture was filtered through a layer of celite $(\sim 2 \mathrm{~cm})$. The filter was washed with dichloromethane, the organic fraction was concentrated, suspended in methanol $(400 \mathrm{~mL})$ containing ammonium fluoride (7.41 g, $200 \mathrm{mmol}, 4$ eq.) and stirred at room temperature overnight ( $c a 16$ hours) until complete cleavage of disiloxyl group (TLC - System I). The reaction mixture was concentrated, 
poured into saturated sodium bicarbonate solution $(600 \mathrm{~mL})$ and extracted with dichloromethane ( $3 \times 200 \mathrm{~mL}$ ). The combined organic layers were dried over $\mathrm{MgSO}_{4}$, filtered, concentrated and coevaporated with toluene $(3 \times 250 \mathrm{~mL})$. The crude mixture was purified by silica gel column chromatography using a gradient of dichloromethane - methanol from 100:0 (v/v) to 94:6 (v/v). $N^{2}$-Isobutyryl-2'-O-(tert-butyldithiomethyl)guanosine (4b) $(10.64 \mathrm{~g}, 21.82 \mathrm{mmol})$ was isolated as a foam with $44 \%$ yield, calculated from 1b. ${ }^{1} \mathrm{H}-\mathrm{NMR}\left(270 \mathrm{MHz}, \mathrm{CDCl}_{3}\right.$ ): $\delta 12.25$ (br. s, $1 \mathrm{H}$ ); 9.65 (br. s, 1H); 8.13 (s, 1H); $5.97(\mathrm{~d}, \mathrm{~J}=5.3 \mathrm{~Hz}, 1 \mathrm{H}) ; 4.90 \& 4.83(2 \mathrm{xd}, \mathrm{J}=11.1 \mathrm{~Hz}, 2 \mathrm{H}) ; 4.78$ (d, J = 5.2 Hz, 1H); 4.67 (br. dd, J = 3.6 Hz, J = 3.7 Hz, 1H); 4.26 (br. d, J = 2.7 Hz, 1H); 4.15 (br. d, 1H); $3.97 \& 3.86(2 x b r . d, J=11.5 \mathrm{~Hz}, 2 \mathrm{H}) ; 2.81(\mathrm{se}, \mathrm{J}=6.9 \mathrm{~Hz}, 1 \mathrm{H}) ; 1.26(\mathrm{~d}, \mathrm{~J}=6.9 \mathrm{~Hz}$, $6 \mathrm{H}) ; 1.23$ (s, 9H). HRMS (FAB) calc for $\mathrm{C}_{19} \mathrm{H}_{30} \mathrm{~N}_{5} \mathrm{O}_{6} \mathrm{~S}_{2}\left(\mathrm{M}+\mathrm{H}^{+}\right)$488.1638, found 488.1680.

$N^{2}$-Isobutyryl-5'-O-(4,4'-dimethoxytrityl)-2'-O-(tert-butyldithiomethyl)guanosine (5b). $N^{2}$ Isobutyryl-2'-O-(tert-butyldithiomethyl)guanosine (4b) (10.64 g, $21.82 \mathrm{mmol}, 1$ eq.) was dissolved in anhydrous pyridine $(150 \mathrm{~mL})$ and 4,4'-dimethoxytrityl chloride ( $8.87 \mathrm{~g}, 26.18 \mathrm{mmol}, 1.2$ eq.) was added. The reaction mixture was stirred at room temperature until

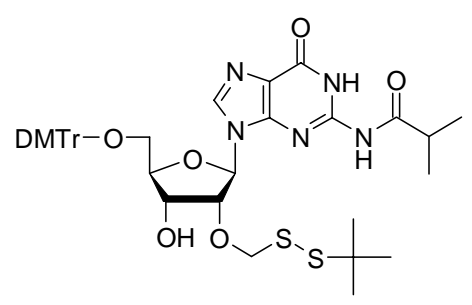
the complete conversion of the starting material ( 2 hours), which was monitored by TLC (System I). Then the reaction mixture was poured into saturated sodium bicarbonate solution (300 $\mathrm{ml})$ and extracted with dichloromethane $(3 \times 100 \mathrm{~mL})$. The combined organic layers were dried over $\mathrm{MgSO}_{4}$, filtered, concentrated and co-evaporated with toluene $(3 \times 100 \mathrm{~mL})$. The crude mixture was purified by silica gel column chromatography using a gradient of petroleum ether - ethyl acetate from 70:30 (v/v, with addition of $0.5 \%$ TEA) to 0:100 (v/v). $N^{2}$-Isobutyryl-5'-O-(4,4'dimethoxytrityl)-2'-O-(tert-butyldithiomethyl)guanosine (5b) (13.86 g, $17.55 \mathrm{mmol})$ was isolated as a light yellow foam with $80 \%$ yield. ${ }^{1} \mathrm{H}-\mathrm{NMR}\left(270 \mathrm{MHz}, \mathrm{CDCl}_{3}+\mathrm{DABCO}\right): \delta 7.95$ (br. s, 
1H); $7.83(\mathrm{~s}, 1 \mathrm{H}) ; 7.54-7.16(\mathrm{~m}, 9 \mathrm{H}) ; 6.81-6.75(\mathrm{~m}, 4 \mathrm{H}) ; 5.91(\mathrm{~d}, \mathrm{~J}=6.9 \mathrm{~Hz}, 1 \mathrm{H}) ; 5.24(\mathrm{dd}, \mathrm{J}=$ $5.1 \mathrm{~Hz}, \mathrm{~J}=6.8 \mathrm{~Hz}, 1 \mathrm{H}) ; 4.97 \& 4.68(2 \mathrm{xd}, \mathrm{J}=11.3 \mathrm{~Hz}, 2 \mathrm{H}) ; 4.60(\mathrm{dd}, \mathrm{J}=5.0 \mathrm{~Hz}, \mathrm{~J}=2.5 \mathrm{~Hz}$, 1H); $4.21(\mathrm{~m}, 1 \mathrm{H}) ; 3.75,3.73(2 \mathrm{xs}, 6 \mathrm{H}) ; 3.52(\mathrm{dd}, \mathrm{J}=10.8 \mathrm{~Hz}, \mathrm{~J}=1.9 \mathrm{~Hz}, 1 \mathrm{H}) ; 3.13(\mathrm{dd}, \mathrm{J}=10.8$ $\mathrm{Hz}, \mathrm{J}=3.2 \mathrm{~Hz}, 1 \mathrm{H}) ; 1.67(\mathrm{se}, \mathrm{J}=6.8 \mathrm{~Hz}, 1 \mathrm{H}) ; 1.23(\mathrm{~s}, 9 \mathrm{H}) ; 0.90 \& 0.69(2 \mathrm{xd}, \mathrm{J}=6.8 \mathrm{~Hz}, 6 \mathrm{H})$. HRMS (FAB) calc for $\mathrm{C}_{40} \mathrm{H}_{48} \mathrm{~N}_{5} \mathrm{O}_{8} \mathrm{~S}_{2}\left(\mathrm{M}+\mathrm{H}^{+}\right)$790.2944, found 790.2964.

\section{$N^{2}$-Isobutyryl-5'-O-(4,4'-dimethoxytrityl)-2'-O-(tert-butyldithiomethyl)guanosine $\quad$ 3'-O-(2-} cyanoethyl $N, N$-diisopropylphosphoramidite) $\quad(6 \mathbf{b})$. To the solution of $\quad N^{2}$-isobutyryl-5'-O-(4,4'-dimethoxytrityl)-2'-O-(tertbutyldithiomethyl)guanosine (5b) $(9.0 \mathrm{~g}, 11.4 \mathrm{mmol}, 1 \mathrm{eq}$.$) in$ anhydrous dichloromethane $(100 \mathrm{~mL})$ containing triethylamine $(9.6$

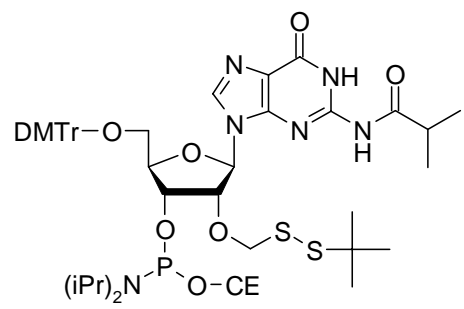
$\mathrm{mL}, 68.4 \mathrm{mmol}, 6$ eq.) 2-cyanoethyl- $N, N$-diisopropylchlorophosphoramidite $(6.4 \mathrm{~mL}, 28.5 \mathrm{mmol}$, 2.5 eq.) was added. The reaction mixture was stirred under argon at room temperature until complete conversion of the starting material ( 2 hours), which was monitored by TLC (System III). Then the reaction was quenched by stirring with methanol $(5 \mathrm{~mL})$ for 20 minutes. The reaction mixture was poured into saturated sodium bicarbonate solution $(150 \mathrm{~mL})$ and extracted with dichloromethane $(2 \times 100 \mathrm{~mL})$. The combined organic layers were dried over $\mathrm{MgSO}_{4}$, filtered and concentrated. The crude mixture was purified by silica gel column chromatography using a gradient of cyclohexane - ethyl acetate from 90:10 (v/v) to 0:100 (v/v) with $5 \mathrm{~mL}$ pyridine added per $100 \mathrm{~mL}$ of mobile phase (pyridine was used instead of triethylamine to ease the purification of the relatively polar $\mathbf{6 b}$ ). Collected fractions were evaporated and re-dissolved in dichloromethane $(34 \mathrm{~mL})$. A 2 L E-flask was filled with hexane $(800 \mathrm{~mL})$ and placed into an ethanol bath at $-78^{\circ} \mathrm{C}$. The dichloromethane solution was added dropwise to the stirred hexane solution, and the amidite precipitated immediately as a white solid. The cold solid was filtered 
through a sintered filtration funnel and washed with cold hexane. The obtained residue was dissolved in dichloromethane and concentrated. $N^{2}$-Isobutyryl-5' $-O$-(4,4'-dimethoxytrityl)-2'-O(tert-butyldithiomethyl)guanosine 3 '-O-(2-cyanoethyl $\mathrm{N}, \mathrm{N}$-diisopropylphosphoramidite)

(7.65 g, $7.73 \mathrm{mmol}$ ) was isolated as a white foam with $68 \%$ yield. ${ }^{31} \mathrm{P}-\mathrm{NMR}\left(\mathrm{CDCl}_{3}\right.$ with DABCO): 151.01, 150.85; HRMS (FAB) calc for $\mathrm{C}_{49} \mathrm{H}_{65} \mathrm{~N}_{7} \mathrm{O}_{9} \mathrm{PS}_{2}\left(\mathrm{M}+\mathrm{H}^{+}\right)$990.4024, found 990.4051

\section{$N^{4}$-Benzoyl-2'-O-(tert-butyldithiomethyl)cytidine (4c).}

\section{Step 1: $N^{4}$-benzoyl-3',5'-O-(1,1,3,3-tetraisopropyldisiloxane-1,3-diyl)cytidine.}

$N^{4}$-Benzoylcytidine (1c) (17.37 g, 50 mmol, 1 eq.) was co-evaporated with anhydrous pyridine $(3 \times 250 \mathrm{~mL})$ and re-dissolved in anhydrous pyridine (250 mL). 1,3-Dichloro-1,1,3,3-tetraisopropyldisiloxane (19.19 $\mathrm{mL}, 60 \mathrm{mmol}, 1.2$ eq.) was added thereto and the reaction mixture was stirred at room temperature until completion (3.5 hours), which was

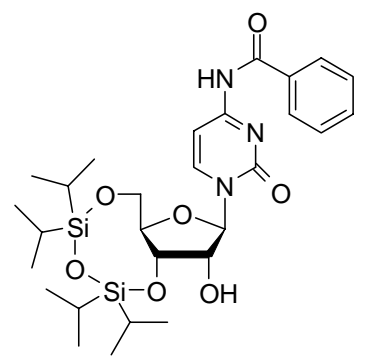
monitored by TLC (System I). The reaction mixture was poured slowly into saturated aqueous sodium bicarbonate solution $(600 \mathrm{~mL})$ and extracted with dichloromethane $(3 \times 150 \mathrm{~mL})$. The combined organic layers were dried over $\mathrm{MgSO}_{4}$, filtered, concentrated to syrup and coevaporated with toluene $(3 \times 250 \mathrm{~mL})$. The obtained crude $N^{4}$-benzoyl-3', $5^{\prime}-O-(1,1,3,3-$ tetraisopropyldisiloxane-1,3-diyl)cytidine was used in the next step without purification.

\section{Step 2: $N^{4}$-benzoyl-3',5'-O-(1,1,3,3-tetraisopropyldisiloxane-1,3-diyl)-} 2'-O-[(methylthio)methyl $]$ cytidine (2c). The crude $N^{4}$-benzoyl-3',5'-O(1,1,3,3-tetraisopropyldisiloxane-1,3-diyl)cytidine obtained from the previous step was dissolved in DMSO $(50 \mathrm{~mL})$ followed by addition of

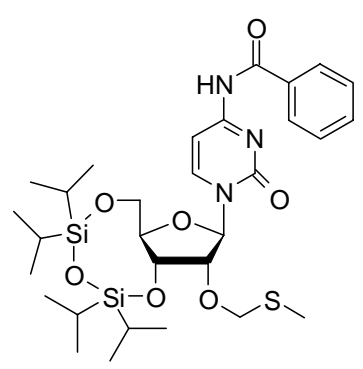
acetic acid $(50 \mathrm{~mL})$ and acetic anhydride $(33 \mathrm{~mL})$. The reaction mixture was stirred at room 
temperature until completion ( $24 \mathrm{~h}$ ), which was monitored by TLC (System I). Then the reaction mixture was transferred to a 2 L E-flask. Potassium carbonate (104 g) was dissolved in water $(800 \mathrm{~mL})$ and the resulting solution was added slowly to the reaction mixture under vigorous stirring. The precipitated product was filtered, re-dissolved in a small volume of THF and precipitated again from water $(800 \mathrm{~mL})$. The obtained residue was dissolved and co-evaporated with pyridine $(1 \times 250 \mathrm{~mL})$, toluene $(3 \times 250 \mathrm{~mL})$ and finally dichloromethane $(1 \times 250 \mathrm{~mL}) . N^{4}-$ Benzoyl-3',5' -O-(1,1,3,3-tetraisopropyldisiloxane-1,3-diyl)-2'-O-[(methylthio)methyl]-cytidine

(2c) (37 g) was obtained as a foam and was used in the next step without further purification. A portion of the compound $(100 \mathrm{mg})$ was purified for the analysis. ${ }^{1} \mathrm{H}-\mathrm{NMR}\left(270 \mathrm{MHz}, \mathrm{CDCl}_{3}\right): \delta$ 8.98 (br. s, 1H) NH; 8.36 (d, J = 7.4 Hz, 1H) H6; 7.93-7.89 (m, 2H); 7.66-7.48 (m, 4H); 5.85 (s, 1H); 5.14 \& $5.00(2 x d, J=11.3 \mathrm{~Hz}, 2 \mathrm{H}) ; 4.39-4.41(\mathrm{~m}, 1 \mathrm{H}) ; 4.31(\mathrm{~d}, \mathrm{~J}=13.5 \mathrm{~Hz}, 1 \mathrm{H}) ; 4.22(\mathrm{~d}, \mathrm{~J}$ $=2.2 \mathrm{~Hz}, 2 \mathrm{H}) ; 4.01(\mathrm{~d}, \mathrm{~J}=13.6 \mathrm{~Hz}, 1 \mathrm{H}), 2.21(\mathrm{~s}, 3 \mathrm{H}) ; 1.21-0.92(\mathrm{~m}, 28 \mathrm{H})$.

Step 3: the obtained crude $N^{4}$-benzoyl-3',5'-O-(1,1,3,3-tetraisopropyldisiloxane-1,3-diyl)-2'-O[(methylthio)methyl]cytidine (2c) was dissolved in anhydrous dichloromethane $(200 \mathrm{~mL})$ containing triethylamine $(6.62 \mathrm{~mL}, 47.5 \mathrm{mmol}$, 0.95 eq.), and molecular sieves were added ( $3 \AA$, $10 \mathrm{~mL})$. The reaction mixture was stirred at room temperature for $30 \mathrm{~min}$ and then cooled in an

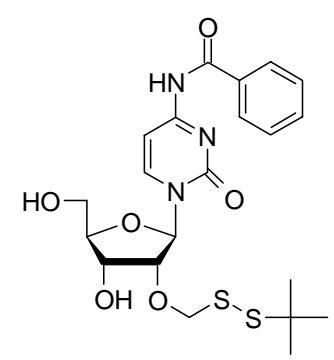
ice-bath. A solution of sulfuryl chloride $(3.82 \mathrm{~mL}, 47.5 \mathrm{mmol}, 0.95$ eq.) in anhydrous dichloromethane $(50 \mathrm{~mL})$ was added dropwise to the reaction mixture during 30 minutes. Then the ice-bath was removed and the reaction mixture was stirred further for 30 minutes followed by addition of potassium thiotosylate (16.98 g, $75 \mathrm{mmol}, 1.5$ eq.) in dry DMF (25 mL). Stirring at room temperature was continued for additional 30 minutes followed by addition of tert-butyl mercaptan (10.71 mL, $100 \mathrm{mmol}, 2$ eq.). The reaction mixture was stirred at room temperature 
for 30 minutes and filtered through a layer of celite $(\sim 2 \mathrm{~cm})$. The filter was washed with dichloromethane, and the organic fraction was concentrated, suspended in methanol (250 $\mathrm{mL})$ containing ammonium fluoride (7.41 g, $200 \mathrm{mmol}, 4$ eq.) and stirred at room temperature overnight ( $\mathrm{ca} 16$ hours) until complete cleavage of the disiloxyl group (TLC - System I). The reaction mixture was poured into saturated sodium bicarbonate solution $(500 \mathrm{~mL})$, and extracted with dichloromethane $(3 \times 200 \mathrm{~mL})$. The combined organic layers were dried over $\mathrm{MgSO}_{4}$, filtered, concentrated and co-evaporated with toluene $(3 \times 250 \mathrm{~mL})$. The crude mixture was purified by silica gel column chromatography using a gradient of dichloromethane - methanol from 100:0 (v/v) to 94:6 (v/v). $N^{4}$-Benzoyl-2'-O-(tert-butyldithiomethyl)cytidine (4c) (13.76 g, $28.57 \mathrm{mmol})$ was obtained as a foam with $57 \%$ yield, calculated from 1c. ${ }^{1} \mathrm{H}-\mathrm{NMR}(270 \mathrm{MHz}$, $\left.\mathrm{CDCl}_{3}\right): \delta 8.89$ (br. s, $\left.1 \mathrm{H}\right) ; 8.36(\mathrm{~d}, \mathrm{~J}=7.4 \mathrm{~Hz}, 1 \mathrm{H}) ; 7.91-7.88(\mathrm{~m}, 2 \mathrm{H}) ; 7.64-7.48(\mathrm{~m}, 4 \mathrm{H}) ; 5.84$ $(\mathrm{d}, \mathrm{J}=2.1 \mathrm{~Hz}, 1 \mathrm{H}) ; 5.14 \& 5.05(2 \mathrm{xd}, \mathrm{J}=11.1 \mathrm{~Hz}, 2 \mathrm{H}) ; 4.52(\mathrm{dd}, \mathrm{J}=2.2 \mathrm{~Hz}, \mathrm{~J}=5.3 \mathrm{~Hz}, 1 \mathrm{H})$; 4.41 (br. m, 1H); 4.15-4.09 (m, 2H); 3.94 (br. d, J = $12.7 \mathrm{~Hz}, 1 \mathrm{H}) ; 1.32$ (s, 9H). HRMS (FAB) calc for $\mathrm{C}_{21} \mathrm{H}_{28} \mathrm{~N}_{3} \mathrm{O}_{6} \mathrm{~S}_{2}\left(\mathrm{M}+\mathrm{H}^{+}\right)$482.1420, found 482.1392 .

$N^{4}$-Benzoyl-5'-O-(4,4'-dimethoxytrityl)-2'-O-(tert-butyldithiomethyl)cytidine $\quad(5 \mathrm{c}) . \quad N^{4}-$ Benzoyl-2'-O-(tert-butyldithiomethyl)cytidine (4c) (13.76 g, 28.57 mmol, 1 eq.) was dissolved in anhydrous pyridine (150 mL), and 4,4'dimethoxytrityl chloride (11.62 g, $34.28 \mathrm{mmol}, 1.2$ eq.) was added. The reaction mixture was stirred at room temperature until the reaction was

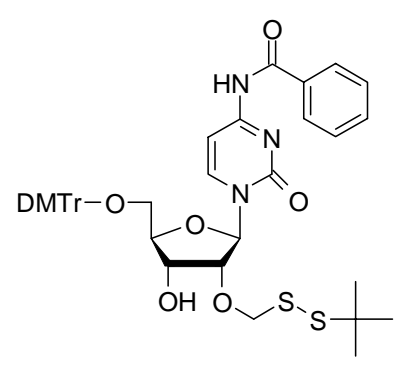
complete ( 2 hours), which was monitored by TLC (System I). The reaction mixture was poured into saturated sodium bicarbonate solution $(500 \mathrm{~mL})$ and extracted with dichloromethane $(3 \times 150$ $\mathrm{mL}$ ). The combined organic layers were dried over $\mathrm{MgSO}_{4}$, filtered, concentrated and coevaporated with toluene $(3 \times 150 \mathrm{~mL})$. The crude mixture was dissolved in dichloromethane $(15$ 
$\mathrm{mL}$ ) followed by addition of methanol $(145 \mathrm{~mL})$, and the crystallization was initiated by adding seed crystals. After 5 hours at room temperature the crystallized product was filtered, washed with several portions of methanol and pentane, and dried under vacuum. The supernatant was concentrated and crystallized again. The combined crystallization afforded $N^{4}$-benzoyl-5'-O(4,4'-dimethoxytrityl)-2'-O-(tert-butyldithiomethyl)cytidine (5c) $(16.83 \mathrm{~g}, 21.47 \mathrm{mmol})$ as light

yellow crystals with $75 \%$ yield. ${ }^{1} \mathrm{H}-\mathrm{NMR}\left(270 \mathrm{MHz}, \mathrm{CDCl}_{3}+\mathrm{DABCO}\right): \delta 8.82$ (br. s, $\left.1 \mathrm{H}\right) ; 8.54$ $(\mathrm{d}, \mathrm{J}=7.4 \mathrm{~Hz}, 1 \mathrm{H}) ; 7.89-7.86(\mathrm{~m}, 2 \mathrm{H}) ; 7.62-7.18(\mathrm{~m}, 13 \mathrm{H}) ; 6.89-6.85(\mathrm{~m}, 4 \mathrm{H}) ; 5.98(\mathrm{~s}, 1 \mathrm{H}) ; 5.23$ \& $5.11(2 x d, J=11.1 \mathrm{~Hz}, 2 \mathrm{H}) ; 4.54-4.49$ (br. m, 1H); $4.34(\mathrm{~d}, \mathrm{~J}=5.3 \mathrm{~Hz}, 1 \mathrm{H}) ; 4.10$ (br. d, J = 8.9 $\mathrm{Hz}, 1 \mathrm{H}) ; 3.81$ (s, 6H); 3.57 (br. s, 2H), 1.34 (s, 9H). HRMS (FAB) calc for $\mathrm{C}_{42} \mathrm{H}_{46} \mathrm{~N}_{3} \mathrm{O}_{8} \mathrm{~S}_{2}(\mathrm{M}+$ $\left.\mathrm{H}^{+}\right)$784.2726, found 784.2668.

\section{$N^{4}$-Benzoyl-5'-O-(4,4'-dimethoxytrityl)-2'-O-(tert-butyldithiomethyl)cytidine $\quad$ 3'-O-(2-} cyanoethyl $N, N$-diisopropylphosphoramidite) $(6 \mathbf{c}) . \quad N^{4}$-Benzoyl dimethoxytrityl)-2'-O-(tert-butyldithiomethyl)cytidine (5c) (13.54 g, $17.3 \mathrm{mmol}, 1$ eq.) was dissolved in anhydrous dichloromethane (150 $\mathrm{mL})$ containing triethylamine (12.0 $\mathrm{mL} 86.4 \mathrm{mmol}, 5$ eq.). 2-

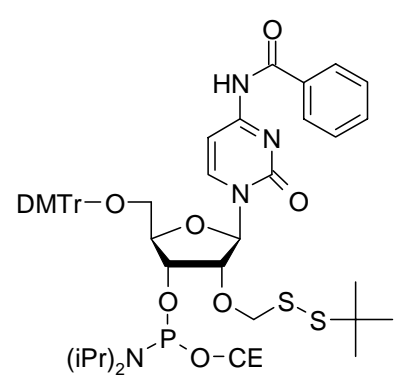
Cyanoethyl $N, N$-diisopropylchlorophosphoramidite $(6.55 \mathrm{~mL}, 29.4 \mathrm{mmol}, 1.7$ eq.) was added and the reaction mixture was stirred at room temperature under argon until full conversion of the starting material ( 2 hours), which was monitored by TLC (System III). Then the reaction was quenched by stirring with methanol $(5 \mathrm{~mL})$ for 20 minutes. The reaction mixture was poured into saturated sodium bicarbonate solution $(300 \mathrm{~mL})$, and extracted with dichloromethane $(2 \times 150$ $\mathrm{mL}$ ). The combined organic layers were dried over $\mathrm{MgSO}_{4}$, filtered and concentrated. The crude mixture was purified by silica gel column chromatography using a gradient of cyclohexane ethyl acetate from 95:5 (v/v) to 10:90 (v/v) with $3 \mathrm{~mL}$ triethylamine added per $100 \mathrm{~mL}$ of mobile 
phase. Collected fractions were evaporated and re-dissolved in dichloromethane $(45 \mathrm{~mL})$. A $2 \mathrm{~L}$ E-flask was filled with hexane $(1100 \mathrm{~mL})$ and placed into an ethanol bath at $-78^{\circ} \mathrm{C}$. The dichloromethane solution was added dropwise to the stirred hexane solution, and the amidite precipitated immediately as a white solid. The cold solid was filtered through a sintered filtration funnel and washed with cold hexane. The obtained residue was dissolved in dichloromethane and concentrated. $N^{4}$-Benzoyl-5'-O-(4,4'-dimethoxytrityl)-2'-O-(tert-butyldithiomethyl)cytidine 3'$O$-(2-cyanoethyl $\mathrm{N}, \mathrm{N}$-diisopropylphosphoramidite) $(\mathbf{6 c})(15.00 \mathrm{~g}, 15.2 \mathrm{mmol})$ was obtained as a white foam with $88 \%$ yield. ${ }^{31} \mathrm{P}-\mathrm{NMR}\left(\mathrm{CDCl}_{3}\right.$ with $\left.\mathrm{DABCO}\right) 150.89,150.73 \mathrm{ppm}$; HRMS (FAB) calc for $\mathrm{C}_{51} \mathrm{H}_{63} \mathrm{~N}_{5} \mathrm{O}_{9} \mathrm{PS}_{2}\left(\mathrm{M}+\mathrm{H}^{+}\right) 984.3805$, found 984.3832

\section{2'-O-(tert-Butyldithiomethyl)uridine (4d).}

Step 1: 3',5'-O-(1,1,3,3-tetraisopropyldisiloxane-1,3-diyl)uridine. Uridine (1d) (14.65 g, $60 \mathrm{mmol}, 1$ eq.) was co-evaporated with anhydrous pyridine $(3 \times 300 \mathrm{~mL})$, re-dissolved in anhydrous pyridine $(300 \mathrm{~mL})$ and 1,3-dichloro1,1,3,3-tetraisopropyldisiloxane ( $23.0 \mathrm{~mL}, 72 \mathrm{mmol}, 1.2$ eq.) was added. The

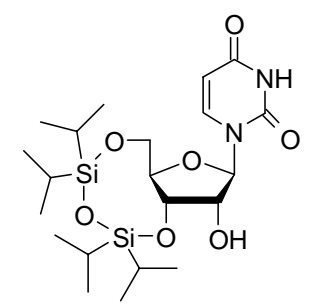
reaction mixture was stirred at room temperature until the reaction was complete ( 3 hours), which was monitored by TLC (System I). The reaction mixture was poured into saturated aqueous sodium bicarbonate solution $(500 \mathrm{~mL})$ and extracted with dichloromethane $(3 \times 200 \mathrm{~mL})$. The combined organic layers were dried over $\mathrm{MgSO}_{4}$, filtered and concentrated to syrup followed by co-evaporation with toluene $(3 \times 300 \mathrm{~mL})$. The obtained crude $3^{\prime}, 5^{\prime}-O-(1,1,3,3-$ tetraisopropyldisiloxane-1,3-diyl)uridine (33.1 g) was used in the next step without purification. 


\section{Step 2: 3',5'-O-(1,1,3,3-tetraisopropyldisiloxane-1,3-diyl)-2'-O-[(methylthio)methyl]uridine}

(2d). To the obtained crude 3',5'-O-(1,1,3,3-tetraisopropyldisiloxane-1,3-

diyl)uridine in DMSO $(60 \mathrm{~mL})$ acetic acid $(90 \mathrm{~mL})$ and acetic anhydride $(60$

$\mathrm{mL}$ ) were added. The reaction mixture was stirred at room temperature until

the reaction was complete ( $24 \mathrm{~h})$, which was monitored by TLC (System II).

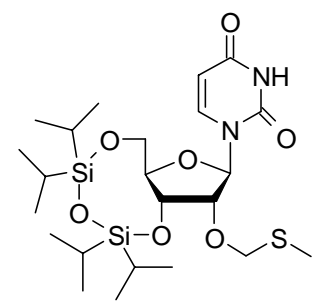

Then the mixture was transferred into a 2 L E-flask. Potassium carbonate (125 g) was dissolved in water $(900 \mathrm{~mL})$ and the resulting solution was added slowly to the reaction mixture under vigorous stirring. The precipitated product was filtered, re-dissolved in a small volume of THF and precipitated again from water $(900 \mathrm{~mL})$. The obtained residue was dissolved and coevaporated with pyridine $(1 \times 300 \mathrm{~mL})$, toluene $(3 \times 300 \mathrm{~mL})$ and finally dichloromethane $(1 \times 300$ $\mathrm{mL})$. The crude 3',5'-O-(1,1,3,3-tetraisopropyldisiloxane-1,3-diyl)-2'-O-[(methylthio)methyl]uridine (2d) (36 g) was obtained as a foam and used in the next step without further purification. A portion $(100 \mathrm{mg})$ of this material was purified by silica gel column chromatography, and the resulting white foam was analyzed. ${ }^{1} \mathrm{H}-\mathrm{NMR}\left(270 \mathrm{MHz}, \mathrm{CDCl}_{3}\right): \delta 9.17$ (br. s, $\left.1 \mathrm{H}\right) ; 7.90(\mathrm{~d}, \mathrm{~J}=$ $8.2 \mathrm{~Hz}, 1 \mathrm{H}) ; 5.74(\mathrm{~s}, 1 \mathrm{H}) ; 5.69(\mathrm{dd}, \mathrm{J}=8.2 \mathrm{~Hz}, \mathrm{~J}=2.0 \mathrm{~Hz}, 1 \mathrm{H}) ; 4.98(\mathrm{~s}, 2 \mathrm{H}) ; 4.36(\mathrm{~d}, \mathrm{~J}=4.3 \mathrm{~Hz}$, 1H); 4.26 (br. d, J = 13.6 Hz, 1H); 4.26-4.20 (m, 1H); $4.14(\mathrm{dd}, \mathrm{J}=9.7 \mathrm{~Hz}, \mathrm{~J}=1.7 \mathrm{~Hz}, 1 \mathrm{H}) ; 3.98$ (dd, J = 13.6 Hz, J = 2.2 Hz, 1H); $2.19(\mathrm{~s}, 3 \mathrm{H}) \mathrm{S}_{-} \mathrm{CH}_{3} ; 1.1-0.9(\mathrm{~m}, 28 \mathrm{H})$. HRMS (FAB) calc for $\mathrm{C}_{22} \mathrm{H}_{28} \mathrm{~N}_{5} \mathrm{O}_{5} \mathrm{~S}_{2}\left(\mathrm{M}+\mathrm{H}^{+}\right)$506.1532, found 506.1525.

Step 3: obtained from the previous step crude $3^{\prime}, 5^{\prime}-O-(1,1,3,3-$ tetraisopropyldisiloxane-1,3-diyl)-2'-O-[(methylthio)methyl]uridine

(2d) was dissolved in anhydrous dichloromethane $(250 \mathrm{~mL})$ containing

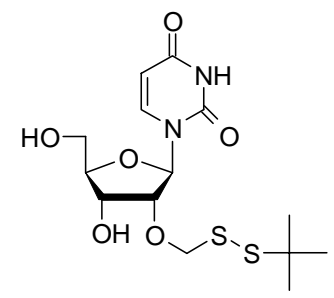
triethylamine (7.94 mL, $57 \mathrm{mmol}, 0.95$ eq.), and molecular sieves were added ( $3 \AA, 10 \mathrm{~mL})$. The reaction mixture was stirred at room temperature for 30 minutes and 
then cooled with an ice-bath. A solution of sulfuryl chloride $(4.58 \mathrm{~mL}, 57 \mathrm{mmol}, 0.95$ eq.) in anhydrous dichloromethane $(50 \mathrm{~mL})$ was added dropwise to the reaction mixture within 40 minutes, and the mixture was stirred for additional 1 hour at $+4^{\circ} \mathrm{C}$. Then a solution of potassium thiotosylate (20.37 g, $90 \mathrm{mmol}, 1.5$ eq.) in dry DMF (35 mL) was added, and the reaction mixture was stirred at room temperature for 30 minutes followed by addition of tert-butyl mercaptan (12.9 mL, $120 \mathrm{mmol}, 2$ eq.). After 30 minutes stirring at room temperature the reaction mixture was passed through a layer of celite $(\sim 2 \mathrm{~cm})$. The filter was washed with dichloromethane and the collected organic phases were concentrated and suspended in methanol (300 mL). Ammonium fluoride (8.89 g, $240 \mathrm{mmol}, 4$ eq.) was added and the reaction mixture was stirred at room temperature overnight ( $\mathrm{ca} 16$ hours) until the cleavage of disiloxyl group was complete (TLC System I). The reaction mixture was concentrated, poured into saturated sodium bicarbonate solution $(600 \mathrm{~mL})$ and extracted with dichloromethane $(3 \times 200 \mathrm{~mL})$. The combined organic layers were dried over $\mathrm{MgSO}_{4}$, filtered, concentrated and co-evaporated with toluene $(3 \times 300 \mathrm{~mL})$. The crude mixture was purified by silica gel column chromatography using a gradient of dichloromethane - methanol from 100:0 (v/v) to 92:8 (v/v). 2'-O-(tert-Butyldithiomethyl)uridine (4d) (10.10 g, $26.69 \mathrm{mmol})$ was isolated as a foam with $44 \%$ yield, calculated from $\mathbf{1 d}{ }^{1} \mathrm{H}-$ $\operatorname{NMR}\left(270 \mathrm{MHz}, \mathrm{CDCl}_{3}\right): \delta 9.17$ (br. s, $\left.1 \mathrm{H}\right) ; 7.71(\mathrm{~d}, \mathrm{~J}=8.0 \mathrm{~Hz}, 1 \mathrm{H}) ; 5.76(\mathrm{~d}, \mathrm{~J}=4.2 \mathrm{~Hz}, 1 \mathrm{H})$; $5.76(\mathrm{~d}, \mathrm{~J}=7.8 \mathrm{~Hz}, 1 \mathrm{H}) ; 4.98 \& 4.93(2 \mathrm{xd}, \mathrm{J}=11.2 \mathrm{~Hz}, 2 \mathrm{H}) ; 4.52(\mathrm{dd}, \mathrm{J}=5.1 \mathrm{~Hz}, \mathrm{~J}=4.3 \mathrm{~Hz}$, 1H); 4.40 (br. t, J = 5.0 Hz, 1H); $4.11(\mathrm{~m}, 1 \mathrm{H}) ; 4.00$ (dd, J = 12.2 Hz, J = 1.5 Hz, 1H); 3.85 (br. d, $\mathrm{J}=12.2 \mathrm{~Hz}, 1 \mathrm{H}) ; 1.32(\mathrm{~s}, 9 \mathrm{H})$. HRMS (FAB) calc for $\mathrm{C}_{14} \mathrm{H}_{23} \mathrm{~N}_{2} \mathrm{O}_{6} \mathrm{~S}_{2}\left(\mathrm{M}+\mathrm{H}^{+}\right)$379.0998, found 379.1004. 
Butyldithiomethyl)uridine (4d) (26.69 mmol, $10.10 \mathrm{~g})$ was dissolved in anhydrous pyridine (150 mL), and 4,4'-dimethoxytrityl chloride (10.85 g, 32.0 mmol, 1.2 eq.) was added. The reaction mixture was stirred at room temperature until complete conversion of the starting material was

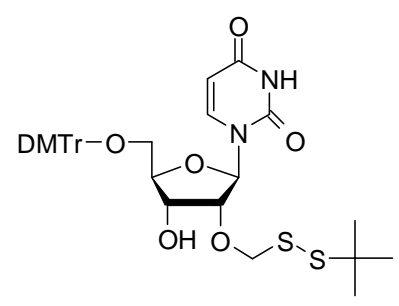
achieved ( 2 hours), which was monitored by TLC (System I). Then the reaction mixture was poured into saturated aqueous sodium bicarbonate solution $(300 \mathrm{~mL})$ and extracted with dichloromethane $(3 \times 150 \mathrm{~mL})$. The combined organic layers were dried over $\mathrm{MgSO}_{4}$, filtered, concentrated and co-evaporated with toluene $(3 \times 130 \mathrm{~mL})$. The crude mixture was purified by silica gel column chromatography using a gradient of petroleum ether - ethyl acetate from 80:20 (v/v, with addition of $0.5 \%$ triethylamine) to $0: 100$ (v/v). 5'-O-(4,4'-Dimethoxytrityl)-2'-O-(tertbutyldithiomethyl)uridine (5d) (14.47 g, $21.25 \mathrm{mmol})$ was isolated as a light yellow foam with $80 \%$ yield. ${ }^{1} \mathrm{H}-\mathrm{NMR}\left(270 \mathrm{MHz}, \mathrm{CDCl}_{3}\right): \delta 7.96(\mathrm{~d}, \mathrm{~J}=8.2 \mathrm{~Hz}, 1 \mathrm{H}) ; 7.40-7.11(\mathrm{~m}, 9 \mathrm{H}) ; 6.87-6.81$ $(\mathrm{m}, 4 \mathrm{H}) ; 5.98(\mathrm{~d}, \mathrm{~J}=2.6 \mathrm{~Hz}, 1 \mathrm{H}) ; 5.28(\mathrm{~d}, \mathrm{~J}=8.0 \mathrm{~Hz}, 1 \mathrm{H}) ; 5.07 \& 4.97(2 \mathrm{xd}, \mathrm{J}=11.1 \mathrm{~Hz}, 2 \mathrm{H})$; $4.53(\mathrm{dd}, \mathrm{J}=5.4 \mathrm{~Hz}, \mathrm{~J}=6.1 \mathrm{~Hz}, 1 \mathrm{H}) ; 4.36(\mathrm{dd}, \mathrm{J}=2.6 \mathrm{~Hz}, \mathrm{~J}=5.3 \mathrm{~Hz}, 1 \mathrm{H}) ; 4.08(\mathrm{dt}, \mathrm{J}=6.7 \mathrm{~Hz}, \mathrm{~J}$ $=2.2 \mathrm{~Hz}, 1 \mathrm{H}) ; 3.79(\mathrm{~s}, 6 \mathrm{H}) ; 3.51(\mathrm{~d}, \mathrm{~J}=2.1 \mathrm{~Hz}, 2 \mathrm{H}) ; 1.34(\mathrm{~s}, 9 \mathrm{H})$. HRMS $(\mathrm{FAB})$ calc for $\mathrm{C}_{35} \mathrm{H}_{41}$ $\mathrm{N}_{2} \mathrm{O}_{8} \mathrm{~S}_{2}\left(\mathrm{M}+\mathrm{H}^{+}\right)$681.2304, found 681.2312.

\section{$5 '-O$-(4,4'-Dimethoxytrityl)-2'-O-(tert-butyldithiomethyl)uridine $\quad 3$ '-O-(2-cyanoethyl $\quad N, N$ -} diisopropylphosphoramidite) (6d). 5'-O-(4,4'-Dimethoxytrityl)-2'-O(tert-butyldithiomethyl)uridine (5d) (10.80 g, $15.9 \mathrm{mmol}, 1 \mathrm{eq}$.$) was$ dissolved in anhydrous dichloromethane $(120 \mathrm{~mL})$ containing triethylamine (11.05 mL, $79.3 \mathrm{mmol}, 5$ eq.), and 2-cyanoethyl $N, N$ -

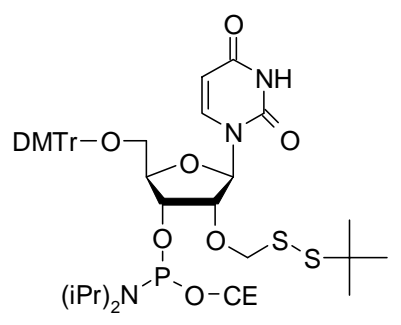
diisopropylchlorophosphoramidite $(6.02 \mathrm{~mL}, 27.0 \mathrm{mmol}, 1.7$ eq. $)$ was added. The reaction 
mixture was stirred at room temperature under argon until complete conversion of the starting material ( 2 hours), which was monitored by TLC (System III). Then the reaction was quenched by stirring with methanol $(8 \mathrm{~mL})$ for 20 minutes. The reaction mixture was poured into saturated sodium bicarbonate solution $(250 \mathrm{~mL})$ and extracted with dichloromethane $(2 \times 100 \mathrm{~mL})$. The combined organic layers were dried over $\mathrm{MgSO}_{4}$, filtered and concentrated in vacuo to a foam. The crude mixture was purified by silica gel column chromatography using a gradient of cyclohexane - ethyl acetate from 95:5 (v/v) to 0:100 (v/v) with $3 \mathrm{~mL}$ triethylamine added per 100 $\mathrm{mL}$ of mobile phase. Collected fractions were evaporated and re-dissolved in dichloromethane (45 mL). A 2 L E-flask was filled with hexane $(1000 \mathrm{~mL})$ and placed into an ethanol bath at $78^{\circ} \mathrm{C}$. The dichloromethane solution was added dropwise to the stirred hexane solution, and the amidite precipitated immediately as a white solid. The cold solid was filtered through a sintered filtration funnel and washed with cold hexane. The obtained residue was dissolved in dichloromethane and concentrated. 5'-O-(4,4'-Dimethoxytrityl)-2'-O-(tert-butyldithiomethyl)uridine 3'- $O$-(2-cyanoethyl $\mathrm{N}, \mathrm{N}$-diisopropylphosphoramidite) $(\mathbf{6 d})(12.0 \mathrm{~g}, 13.8 \mathrm{mmol})$ was isolated as a white foam with $87 \%$ yield. ${ }^{31} \mathrm{P}-\mathrm{NMR}\left(\mathrm{CDCl}_{3}\right.$ with $\left.\mathrm{DABCO}\right) 151.17,150.91 \mathrm{ppm}$; HRMS (FAB) calc for $\mathrm{C}_{44} \mathrm{H}_{58} \mathrm{~N}_{4} \mathrm{O}_{9} \mathrm{PS}_{2}\left(\mathrm{M}+\mathrm{H}^{+}\right)$881.3383, found 881.3458. 


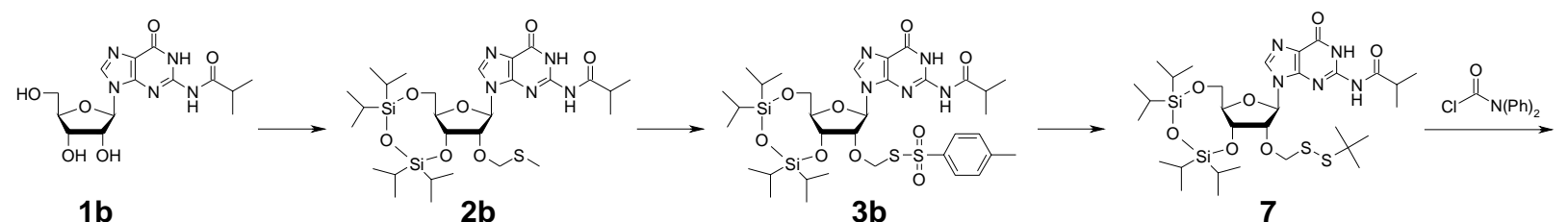

$1 b$

2b

$3 b$

7

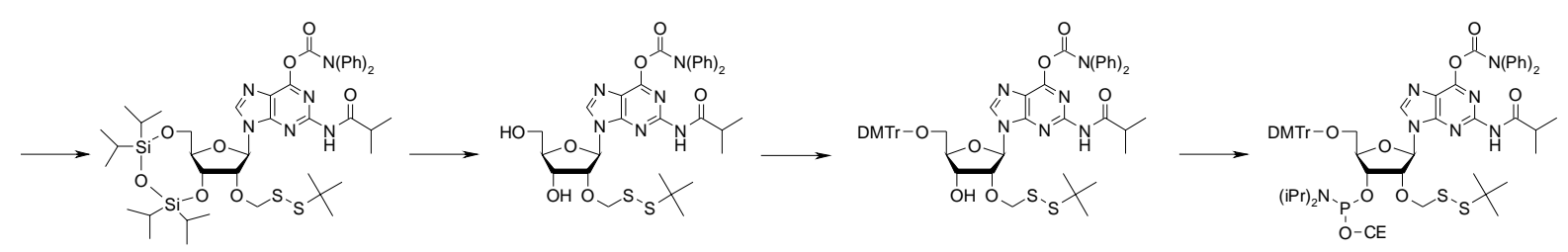

8

9

10

11

Supporting Information Scheme 1. Synthesis of $O^{6}$-DPC protected guanosine phosphoramidite (11).

$N^{2}$-Isobutyryl- $O^{6}$-diphenylcarbamoyl-5' $-O$-(4,4'-dimethoxytrityl)-2'-O-(tertbutyldithiomethyl)guanosine (10).

\section{Step 1: $N^{2}$-isobutyryl-3',5'-O-(1,1,3,3-tetraisopropyldisiloxane-} 1,3-diyl)-2'-O-(tert-butyldithiomethyl)guanosine (7). Crude $N^{2}$ isobutyryl-3',5'-O-(1,1,3,3-tetraisopropyldisiloxane-1,3-diyl)-2'-Omethylthiomethylguanosine (2b), obtained from $N^{2}-$

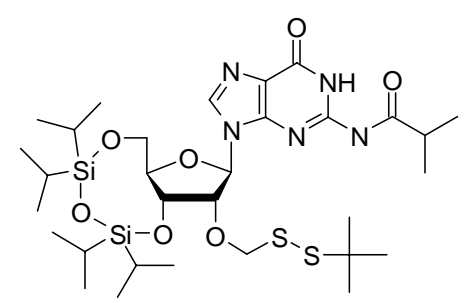
isobutyrylguanosine (1b) (35.33 g, $100 \mathrm{mmol}, 1$ eq.) by the described procedure, was dissolved in anhydrous dichloromethane $(700 \mathrm{~mL})$ and molecular sieves were added ( $3 \AA$, $20 \mathrm{~mL})$. The reaction mixture was stirred at room temperature for 30 minutes and then cooled with an ice-bath. A solution of sulfuryl chloride $(7.63 \mathrm{~mL}, 95 \mathrm{mmol}, 0.95$ eq.) in anhydrous dichloromethane (100 $\mathrm{mL}$ ) was added dropwise to the reaction mixture within 25 minutes followed by addition of cyclohexene (20.3 mL, $200 \mathrm{mmol}, 2$ eq.). Then the ice-bath was removed, and the reaction mixture was stirred for additional 45 minutes. Potassium thiotosylate (33.95 g, $150 \mathrm{mmol}, 1.5$ eq.) in DMF (55 mL) was added to the reaction mixture. The reaction mixture was stirred at room 
temperature for 30 minutes followed by addition of tert-butyl mercaptan $(21.42 \mathrm{~mL}, 200 \mathrm{mmol}, 2$ eq.). After 60 minutes stirring at room temperature the reaction mixture was filtered using celite $(\sim 2 \mathrm{~cm})$. The filter was washed with dichloromethane and the organic fraction was collected, concentrated and extracted from saturated bicarbonate solution $(700 \mathrm{~mL})$ with dichloromethane $(2 \times 350 \mathrm{~mL})$. The combined organic layers were dried over $\mathrm{MgSO}_{4}$, concentrated, and coevaporated with toluene $(3 \times 500 \mathrm{~mL})$. The crude mixture was partially purified by silica gel column chromatography using a gradient of dichloromethane - methanol from 100:0 (v/v) to 95:5 (v/v). $\quad N^{2}$-Isobutyryl-3' ,5' -O-(1,1,3,3-tetraisopropyldisiloxane-1,3-diyl)-2'-O-(tert-butyldithiomethyl)guanosine (24.92 g, $34.1 \mathrm{mmol})$ was isolated as a sticky foam with $34 \%$ yield calculated from $\mathbf{1 b}$.

Step 2: $N^{2}$-isobutyryl- $O^{6}$-diphenylcarbamoyl-2'-O-(tert-butyldithiomethyl)guanosine (9). To the solution of obtained from the previous step $\mathrm{N}^{2}$-isobutyryl-3', $5^{\prime}-\mathrm{O}$ (1,1,3,3-tetraisopropyldisiloxane-1,3-diyl)-2'-O-(tert-butyldithiomethyl)guanosine (7) (3.11 g, $4.26 \mathrm{mmol}, 1$ eq.) in anhydrous pyridine (50 mL) diphenylcarbamyl chloride (1.48 g, $6.39 \mathrm{mmol}, 1.5$ eq.) and $N, N$-diisopropylethylamine $(2.23 \mathrm{~mL}, 12.78 \mathrm{mmol}, 3$ eq.) were added.

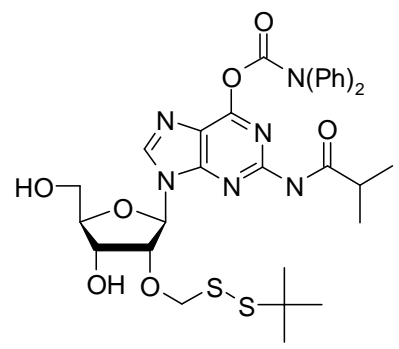
The reaction mixture was stirred under argon at room temperature for 2 hours and then concentrated in vacuo and co-evaporated with toluene $(2 \times 20 \mathrm{~mL})$. The residue was re-dissolved in THF (50 mL) and $1 \mathrm{M}$ solution of tetrabutylammonium fluoride (8.52 mL, $8.52 \mathrm{mmol}, 2$ eq.) in dry THF was added. The reaction mixture was stirred at room temperature for 1 hour and then concentrated in vacuo. Saturated sodium bicarbonate solution $(100 \mathrm{~mL})$ was added and the mixture was extracted with dichloromethane $(3 \times 50 \mathrm{~mL})$. The combined organic layers were dried over $\mathrm{MgSO}_{4}$, filtered and concentrated. The crude mixture was partially purified by silica gel 
column chromatography using a gradient of dichloromethane - methanol from 100:0 (v/v) to 95:5 (v/v). $N^{2}$-Isobutyryl- $O^{6}$-diphenylcarbamoyl-2'-O-(tert-butyldithiomethyl)guanosine (9) (1.79 g, $2.62 \mathrm{mmol})$ was isolated as a foam with $62 \%$ yield. ${ }^{1} \mathrm{H}-\mathrm{NMR}(270 \mathrm{MHz}, \mathrm{CDCl} 3): \delta 8.02(\mathrm{~s}, 1 \mathrm{H})$; 8.00 (br. s, $1 \mathrm{H}) ; 7.43-7.21(\mathrm{~m}, 10 \mathrm{H}) ; 5.94(\mathrm{~d}, \mathrm{~J}=6.6 \mathrm{~Hz}, 1 \mathrm{H}) ; 4.88(\mathrm{dd}, \mathrm{J}=6.4 \mathrm{~Hz}, \mathrm{~J}=4.9 \mathrm{~Hz}$, $1 \mathrm{H}) ; 4.82 \& 4.69(2 \mathrm{xd}, \mathrm{J}=11.1 \mathrm{~Hz}, 2 \mathrm{H}) ; 4.70(\mathrm{~m}, 1 \mathrm{H}) ; 4.26$ (br. d, J = $1.5 \mathrm{~Hz}, 1 \mathrm{H}) ; 3.99(\mathrm{dd}$, $\mathrm{J}=12.6 \mathrm{~Hz}, \mathrm{~J}=1.2 \mathrm{~Hz}, 1 \mathrm{H}) ; 3.80(\mathrm{dd}, \mathrm{J}=12.6 \mathrm{~Hz}, \mathrm{~J}=1.4 \mathrm{~Hz}, 1 \mathrm{H}) ; 2.71(\mathrm{se}, \mathrm{J}=6.8 \mathrm{~Hz}, 1 \mathrm{H}) ; 1.25$ (d, J = 6.8 Hz, 6H); $1.24(\mathrm{~s}, 9 \mathrm{H})$.

Step 3: $N^{2}$-isobutyryl- $O^{6}$-diphenylcarbamoyl-2'-O-(tert-butyldithiomethyl)guanosine (9) (1.79 g, $2.62 \mathrm{mmol}, 1$ eq.) was dissolved in anhydrous pyridine $(50 \mathrm{~mL})$ and 4,4'-dimethoxytrityl chloride (1.07 g, $3.14 \mathrm{mmol}, 1.2$ eq.) was added. The reaction mixture was stirred at room temperature until the reaction was complete ( 2 hours), which was monitored by TLC

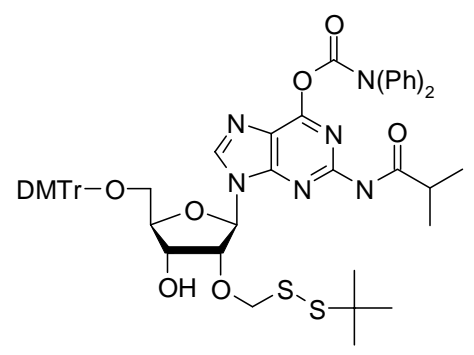
(System I). The reaction mixture was poured into saturated bicarbonate solution (100 mL) and extracted with dichloromethane $(3 \times 50 \mathrm{~mL})$. The combined organic layers were dried over $\mathrm{MgSO}_{4}$, filtered, concentrated and co-evaporated with toluene $(3 \times 15 \mathrm{~mL})$. The crude mixture was purified by silica gel column chromatography using a gradient of petroleum ether - ethyl acetate from 80:20 (v/v, with $0.5 \%$ triethylamine added) to $30: 70 \quad(\mathrm{v} / \mathrm{v}) . \quad N^{2}$-Isobutyryl- $O^{6}-$ diphenylcarbamoyl-5'-O-(4,4'-dimethoxytrityl)-2'-O-(tert-butyldithiomethyl)guanosine

$(1.71 \mathrm{~g}, 1.74 \mathrm{mmol})$ was isolated as a light yellow foam with $66 \%$ yield. ${ }^{1} \mathrm{H}-\mathrm{NMR}$ (270 MHz, $\left.\mathrm{CDCl}_{3}+\mathrm{DABCO}\right): \delta 8.14(\mathrm{~s}, 1 \mathrm{H}) ; 7.78(\mathrm{~s}, 1 \mathrm{H}) ; 7.52-7.14(\mathrm{~m}, 19 \mathrm{H}), 6.81-6.75(\mathrm{~m}, 4 \mathrm{H}) ; 6.13(\mathrm{~d}, \mathrm{~J}$ $=4.1 \mathrm{~Hz}, 1 \mathrm{H}) ; 5.04(\mathrm{~s}, 2 \mathrm{H}) ; 4.90(\mathrm{dd}, \mathrm{J}=4.5 \mathrm{~Hz}, \mathrm{~J}=4.8 \mathrm{~Hz}, 1 \mathrm{H}) ; 4.58(\mathrm{dt}, \mathrm{J}=4.6 \mathrm{~Hz}, \mathrm{~J}=5.1 \mathrm{~Hz}$, 1H); 4.22 (br. m, 1H); $3.74(\mathrm{~s}, 6 \mathrm{H}) ; 3.48(\mathrm{dd}, \mathrm{J}=2.2 \mathrm{~Hz}, \mathrm{~J}=10.7 \mathrm{~Hz}, 1 \mathrm{H}) ; 3.36(\mathrm{dd}, \mathrm{J}=4.1 \mathrm{~Hz}, \mathrm{~J}$ 
$=10.7 \mathrm{~Hz}, 1 \mathrm{H}) ; 2.69(\mathrm{~d}, \mathrm{~J}=5.9 \mathrm{~Hz}, 1 \mathrm{H}) ; 2.60(\mathrm{se}, \mathrm{J}=6.9 \mathrm{~Hz}, 1 \mathrm{H}) ; 1.27(\mathrm{~s}, 9 \mathrm{H}) ; 1.16,1.12(2 \mathrm{xd}$, $\mathrm{J}=6.93 \mathrm{~Hz}, 6 \mathrm{H})$.

$N^{2}$-Isobutyryl- $O^{6}$-diphenylcarbamoyl-5'-O-(4,4'-dimethoxytrityl)-2'-O-(tertbutyldithiomethyl)guanosine 3'-O-(2-cyanoethyl $N, N$-diisopropylphosphoramidite) (11).

To the solution of $N^{2}$-isobutyryl- $O^{6}$-diphenylcarbamoyl-5' $-O-\left(4,4^{\prime}-\right.$ dimethoxytrityl)-2'-O-(tert-butyldithiomethyl)guanosine (10) (1.68 $\mathrm{g}, 1.71 \mathrm{mmol}$, 1 eq.) in anhydrous dichloromethane $(50 \mathrm{~mL})$ containing triethylamine $(1.43 \mathrm{~mL}, 10.26 \mathrm{mmol}, 6$ eq. $)$ 2cyanoethyl- $N, N$-diisopropylchlorophosphoramidite $(0.96 \mathrm{~mL}, 4.28$

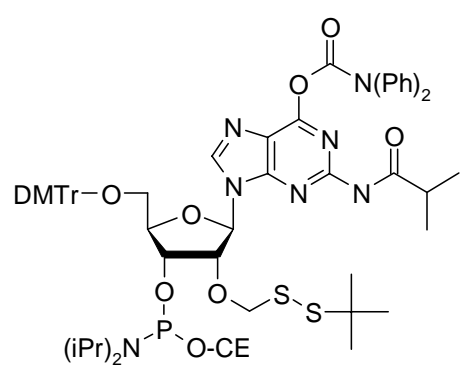
mmol, 2.5 eq.) was added. The reaction mixture was stirred under argon at room temperature until complete conversion of the starting material ( 2 hours), which was monitored by TLC (System III). Then the reaction was quenched by stirring with methanol $(1 \mathrm{~mL})$ for 20 minutes. The reaction mixture was poured into saturated sodium bicarbonate solution $(100 \mathrm{~mL})$, and extracted with dichloromethane $(2 \times 50 \mathrm{~mL})$. The combined organic layers were dried over $\mathrm{MgSO}_{4}$, filtered and concentrated. The crude mixture was purified by silica gel column chromatography using a gradient of cyclohexane - ethyl acetate from 90:10 (v/v) to 20:80 (v/v) with $3 \mathrm{~mL}$ triethylamine added per $100 \mathrm{~mL}$ of mobile phase. $N^{2}$-Isobutyryl- $O^{6}$ diphenylcarbamoyl-5'-O-(4,4'-dimethoxytrityl)-2'-O-(tert-butyldithiomethyl)guanosine 3'-O-(2cyanoethyl $\mathrm{N}, \mathrm{N}$-diisopropylphosphoramidite) (11) (1.63 g, $1.38 \mathrm{mmol})$ was isolated as a white foam with $81 \%$ yield. ${ }^{31} \mathrm{P}-\mathrm{NMR}\left(\mathrm{CDCl}_{3}\right.$ with DABCO): $151.45,151.28 \mathrm{ppm}$.

\section{Oligonucleotide synthesis and deprotection.}

RNA oligonucleotides were synthesized at $0.2 \mu \mathrm{mol}$ scale on ABI 394 DNA/RNA synthesizer using trityl-on mode and 5-ethylthio-1- $H$-tetrazole (ETT) as the activator. Standard ABI CE DNA 
synthesis cycle was employed with coupling time changed to $150 \mathrm{~s}$. Diluted $(0.02 \mathrm{M})$ iodine solution was used for phosphate triester oxidation, and standard DNA synthesis reagents were used for capping and detritylation. Synthesized oligonucleotides were treated with conc. aq. ammonia at $55^{\circ} \mathrm{C}$ for 8 hours. After evaporation of ammonia the removal of DTM groups was accomplished using either DTT $(0.2 \mathrm{~mL}, 0.3 \mathrm{M})$ or TCEP $(0.2 \mathrm{~mL}, 0.3 \mathrm{M})$ in a phosphate buffer $\left(0.2 \mathrm{M}, \mathrm{pH}\right.$ 7.6) at $55^{\circ} \mathrm{C}$ for $90 \mathrm{~min}$. Obtained tritylated RNA was purified using reversed-phase cartridges according to the described methodology ${ }^{1}$.

\section{RNase P RNA mediated cleavage of a model substrate, pATSerUG.}

RNA used in this study was synthesized according to the present DTM method or purchased from Dharmacon. The experiments were performed essentially as described earlier ${ }^{2}$. RNase P RNA mediated cleavage was monitored at $37^{\circ} \mathrm{C}$ under single turnover conditions using $\leq 20 \mathrm{nM}$ substrate concentration and $0.7 \mu \mathrm{M}$ T7 RNA polymerase transcribed Escherichia coli RNase P RNA (M1 RNA) in $50 \mathrm{mM}$ Tris- $\mathrm{HCl}(\mathrm{pH} 7.2), 5 \%$ (w/v) PEG 6000, $100 \mathrm{mM} \mathrm{NH}_{4} \mathrm{Cl}$ and $67 \mathrm{mM}$ $\mathrm{MgCl}_{2}$. M1 RNA was pre-incubated at $37^{\circ} \mathrm{C}$ for $7 \mathrm{~min}$ and mixed with preheated $5^{\prime} \gamma_{-}{ }^{32} \mathrm{P}$ labelled pATSerUG. Samples were withdrawn at indicated time points. The reaction was stopped by adding 4.5 times the volume of warm stop-solution (10 M urea, $10 \mathrm{mM}$ EDTA and bromophenol blue). The cleavage products were separated by $20-22 \%$ denaturing polyacrylamide gel electrophoresis, and the cleavage product was quantified using PhosphoImager. The substrate pATSerUG was $5^{\prime} \gamma^{-32} \mathrm{P}$ labelled according to the standard procedure.

RNase H mediated cleavage of a 22-mer RNA-DNA duplex. The synthesized 22-mer RNA was $5^{\prime} \gamma_{-}{ }^{32} \mathrm{P}$ labelled according to standard procedures. The obtained RNA was mixed with a complementary 22-mer DNA in $50 \mathrm{mM}$ Tris- $\mathrm{HCl}$ (pH 8.3), $75 \mathrm{mM} \mathrm{KCl}, 3 \mathrm{mM} \mathrm{MgCl}_{2}$, heated to $95^{\circ} \mathrm{C}$ for 2 min and cooled to room temperature. The resulting RNA-DNA duplex was preheated 
for 4 min at $37^{\circ} \mathrm{C}$, and 200 units RNase $\mathrm{H}$ (Invitrogen) was added to the mixture. Samples were withdrawn at indicated time points, and the reaction was stopped using the same stop-solution as for the RNase P cleavage assay. As a control we used the same $5^{\prime} \gamma^{32} \mathrm{P}$ labelled 22-mer RNA without complementary DNA fragment.

(1) Semenyuk, A.; Ahnfelt, M.; Estmer, C.; Hao, Y.; Földesi, A.; Kao, Y.-S.; Chen, H. H.; Kao, W.-C.; Peck, K.; Kwiatkowski, M. Anal. Biochem. 2006, Accepted for publication

(2) Kufel, J.; Kirsebom, L. A. RNA 1998, 4, 777-788 


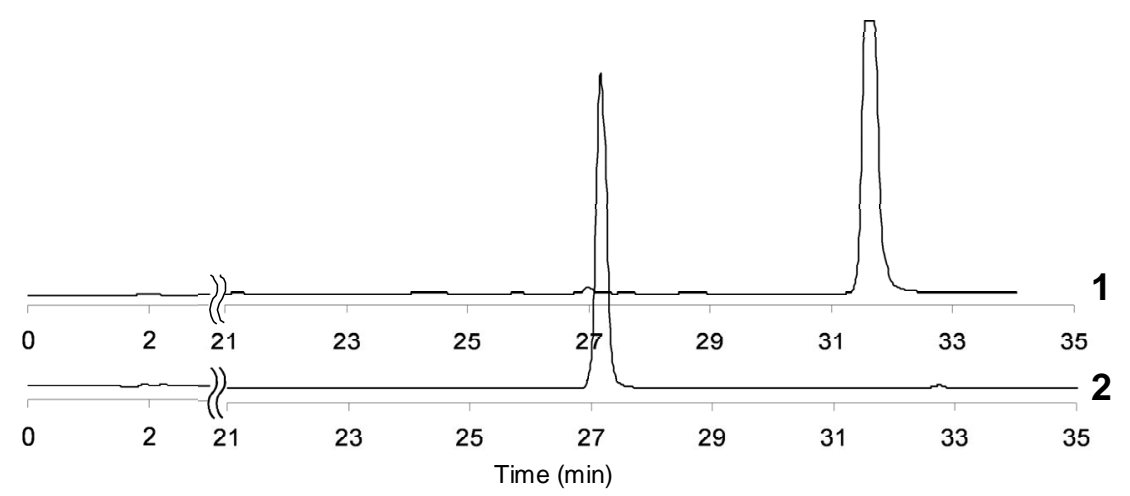

Supporting Information Figure 1. Purity of 2'-O-DTM-uridine (4d). 1) 2'- $O$-DTM-5chlorouridine isolated from the mixture containing both derivatives; 2) Purity of 2'-O-DTMuridine (4d) synthesized according to the present procedure. HPLC: linear gradient from A to $50 \% \mathrm{~B}$ in $40 \mathrm{~min}$.

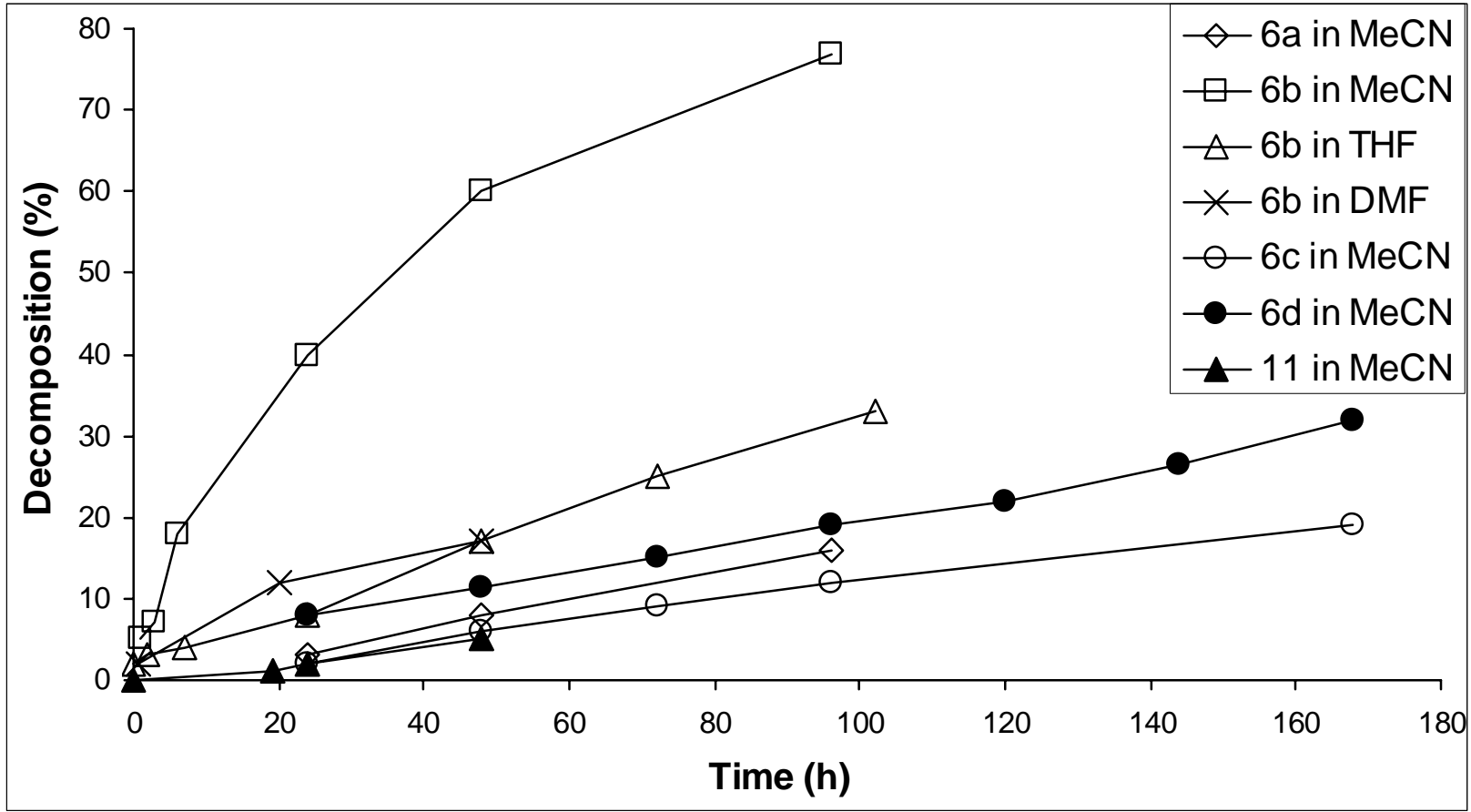

Supporting Information Figure 2. Stability of 2'- $O$-DTM amidites 6a-d and $\mathbf{1 1}$ in specified solvents measured with ${ }^{31} \mathrm{P}$ NMR spectroscopy. 


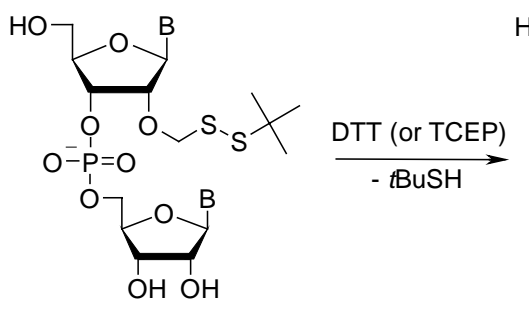

A

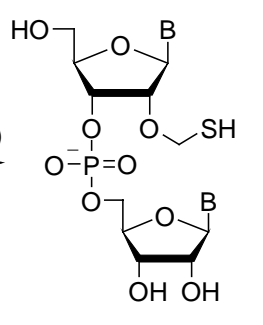

B

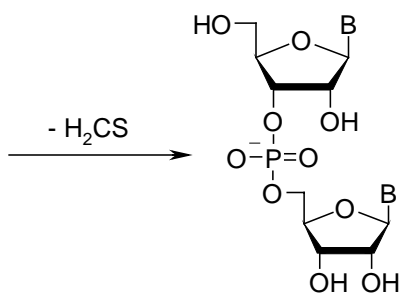

$\mathrm{C}$

Supporting Information Scheme 2. Two step deprotection of a 2'-O-DTM group.

\begin{tabular}{|c|c|c|c|c|c|c|c|c|c|c|c|c|c|c|c|}
\hline \multirow[b]{3}{*}{$\begin{array}{l}\text { time, } \\
\text { min }\end{array}$} & \multicolumn{9}{|c|}{ phosphate buffer } & \multicolumn{6}{|c|}{ borate buffer } \\
\hline & \multicolumn{3}{|c|}{ pH 6.0} & \multicolumn{3}{|c|}{$\mathrm{pH} 7.0$} & \multicolumn{3}{|c|}{ pH 8.0} & \multicolumn{3}{|c|}{ pH 9.0 } & \multicolumn{3}{|c|}{ pH 10.0} \\
\hline & A & B & C & A & B & C & A & B & C & A & B & C & A & B & C \\
\hline 5 & 98.6 & 1.4 & 0 & 83.7 & 12.7 & 3.6 & 46.1 & 24.3 & 29.6 & 28.7 & 9.2 & 62.1 & 0 & 1.5 & 98.5 \\
\hline 30 & 91.9 & 6.9 & 1.2 & 43.6 & 21.4 & 35.0 & 2.6 & 3.1 & 94.3 & 0 & 0 & $\mid 100$ & 0 & 0 & 100 \\
\hline 60 & 84.7 & 11.5 & 3.8 & 20.8 & 13.5 & 65.7 & 0 & 0 & 100 & & & & & & \\
\hline 120 & 71.6 & 17.1 & 11.3 & 5.7 & 4.4 & 89.9 & & & & & & & & & \\
\hline
\end{tabular}

Supporting Information Table 1. Deprotection of 2'-O-DTM-adenosilyl-(5' $\rightarrow 3$ ')-cytidine $(0.1$ $\mathrm{mM}$ in $0.1 \mathrm{M}$ buffer) upon treatment with DTT $(50 \mathrm{mM})$ at $20^{\circ} \mathrm{C}$. Numbers in the table correspond to amounts (\%) of $\mathbf{A}, \mathbf{B}$ and $\mathbf{C}$ (Scheme 2) calculated from HPLC chromatograms.

\begin{tabular}{|c|c|c|c|c|c|c|c|c|c|c|c|c|c|c|c|c|c|c|}
\hline \multirow[b]{3}{*}{$\begin{array}{c}\text { time, } \\
\text { min }\end{array}$} & \multirow{2}{*}{\multicolumn{3}{|c|}{$\begin{array}{c}\text { acetate buffer } \\
\mathrm{pH} 5.0\end{array}$}} & \multicolumn{9}{|c|}{ phosphate buffer } & \multicolumn{6}{|c|}{ borate buffer } \\
\hline & & & & \multicolumn{3}{|c|}{ pH 6.0} & \multicolumn{3}{|c|}{ pH 7.0} & \multicolumn{3}{|c|}{ pH 8.0} & \multicolumn{3}{|c|}{$\mathrm{pH} 9.0$} & \multicolumn{3}{|c|}{ pH 10.0} \\
\hline & A & B & C & A & B & C & A & B & C & A & B & C & A & B & C & A & B & C \\
\hline 5 & 66.0 & 33.2 & 0.8 & 11.6 & 84.2 & 4.2 & 0 & 76.9 & 23.1 & 0 & 66.6 & 33.4 & 0 & 7.9 & 92.1 & 0 & 0 & 100 \\
\hline 30 & 8.5 & 84.4 & 7.1 & 0 & 78.4 & 21.6 & 0 & 25.7 & 74.3 & 0 & 10.4 & 89.6 & 0 & 0 & 100 & & & \\
\hline 60 & 0.6 & 83.6 & 15.8 & 0 & 61.8 & 38.2 & 0 & 6.7 & 93.3 & 0 & 1.0 & 99.0 & & & & & & \\
\hline 120 & 0 & 69.7 & 30.3 & 0 & 38.4 & 61.6 & 0 & 0 & 100 & 0 & 0 & 100 & & & & & & \\
\hline
\end{tabular}

Supporting Information Table 2. Deprotection of 2'- $O$-DTM-adenosilyl-(5' $\left.\rightarrow 3^{\prime}\right)$-cytidine $(0.1$ $\mathrm{mM}$ in $0.1 \mathrm{M}$ buffer) upon treatment with TCEP $(50 \mathrm{mM})$ at $20^{\circ} \mathrm{C}$. Numbers in the table correspond to amounts (\%) of $\mathbf{A}, \mathbf{B}$ and $\mathbf{C}$ (Scheme 2) calculated from HPLC chromatograms. 


\begin{tabular}{|c|c|c|c|c|c|}
\hline \multicolumn{5}{|c|}{ Deprotection conditions } & $t_{\infty}$ \\
\hline dimer & $50 \mathrm{mM}$ & DTT & $\mathrm{pH} 6.8$ & $20^{\circ} \mathrm{C}$ & 20 hours \\
\hline dimer & $50 \mathrm{mM}$ & DTT & $\mathrm{pH} 6.8$ & $55^{\circ} \mathrm{C}$ & $40 \mathrm{~min}$ \\
\hline dimer & $50 \mathrm{mM}$ & DTT & $\mathrm{pH} 8.0$ & $20^{\circ} \mathrm{C}$ & 2 hours \\
\hline dimer & $50 \mathrm{mM}$ & DTT & $\mathrm{pH} 8.0$ & $55^{\circ} \mathrm{C}$ & $10 \mathrm{~min}$ \\
\hline dimer & $50 \mathrm{mM}$ & TCEP & $\mathrm{pH} 7.0$ & $20^{\circ} \mathrm{C}$ & $110 \mathrm{~min}$ \\
\hline dimer & $50 \mathrm{mM}$ & TCEP & $\mathrm{pH} 8.0$ & $20^{\circ} \mathrm{C}$ & $70 \mathrm{~min}$ \\
\hline 12-mer & $50 \mathrm{mM}$ & DTT & $\mathrm{pH} 6.8$ & $20^{\circ} \mathrm{C}$ & 670 hours* \\
\hline 12-mer & $50 \mathrm{mM}$ & DTT & pH 6.8 & $55^{\circ} \mathrm{C}$ & 6 hours \\
\hline 12-mer & $50 \mathrm{mM}$ & DTT & pH 8.0 & $20^{\circ} \mathrm{C}$ & 16 hours \\
\hline 12-mer & $50 \mathrm{mM}$ & DTT & $\mathrm{pH} 8.0$ & $55^{\circ} \mathrm{C}$ & $30 \mathrm{~min}$ \\
\hline 12-mer & $500 \mathrm{mM}$ & DTT & $\mathrm{pH} 6.8$ & $20^{\circ} \mathrm{C}$ & 135 hours* \\
\hline 12-mer & $500 \mathrm{mM}$ & DTT & $\mathrm{pH} 6.8$ & $55^{\circ} \mathrm{C}$ & 6 hours \\
\hline 12-mer & $500 \mathrm{mM}$ & DTT & $\mathrm{pH} 8.0$ & $20^{\circ} \mathrm{C}$ & 14 hours \\
\hline 12-mer & $500 \mathrm{mM}$ & DTT & $\mathrm{pH} 8.0$ & $55^{\circ} \mathrm{C}$ & $30 \mathrm{~min}$ \\
\hline 24-mer & $500 \mathrm{mM}$ & DTT & pH 6.8 & $55^{\circ} \mathrm{C}$ & 6 hours \\
\hline 24-mer & $500 \mathrm{mM}$ & DTT & $\mathrm{pH} 8.0$ & $20^{\circ} \mathrm{C}$ & 14 hours \\
\hline 22-mer & $300 \mathrm{mM}$ & DTT & $\mathrm{pH} 7.6$ & $55^{\circ} \mathrm{C}$ & 1.5 hour \\
\hline 45-mer & $500 \mathrm{mM}$ & DTT & $\mathrm{pH} 7.6$ & $55^{\circ} \mathrm{C}$ & 1.5 hour \\
\hline
\end{tabular}

Supporting Information Table 3. Deprotection conditions for removal of 2'- $O$-DTM groups from oligoribonucleotides $(0.1 \mathrm{mM}$ ) of different lengths (in $0.2 \mathrm{M}$ phosphate buffer). Calculated from HPLC chromatograms.
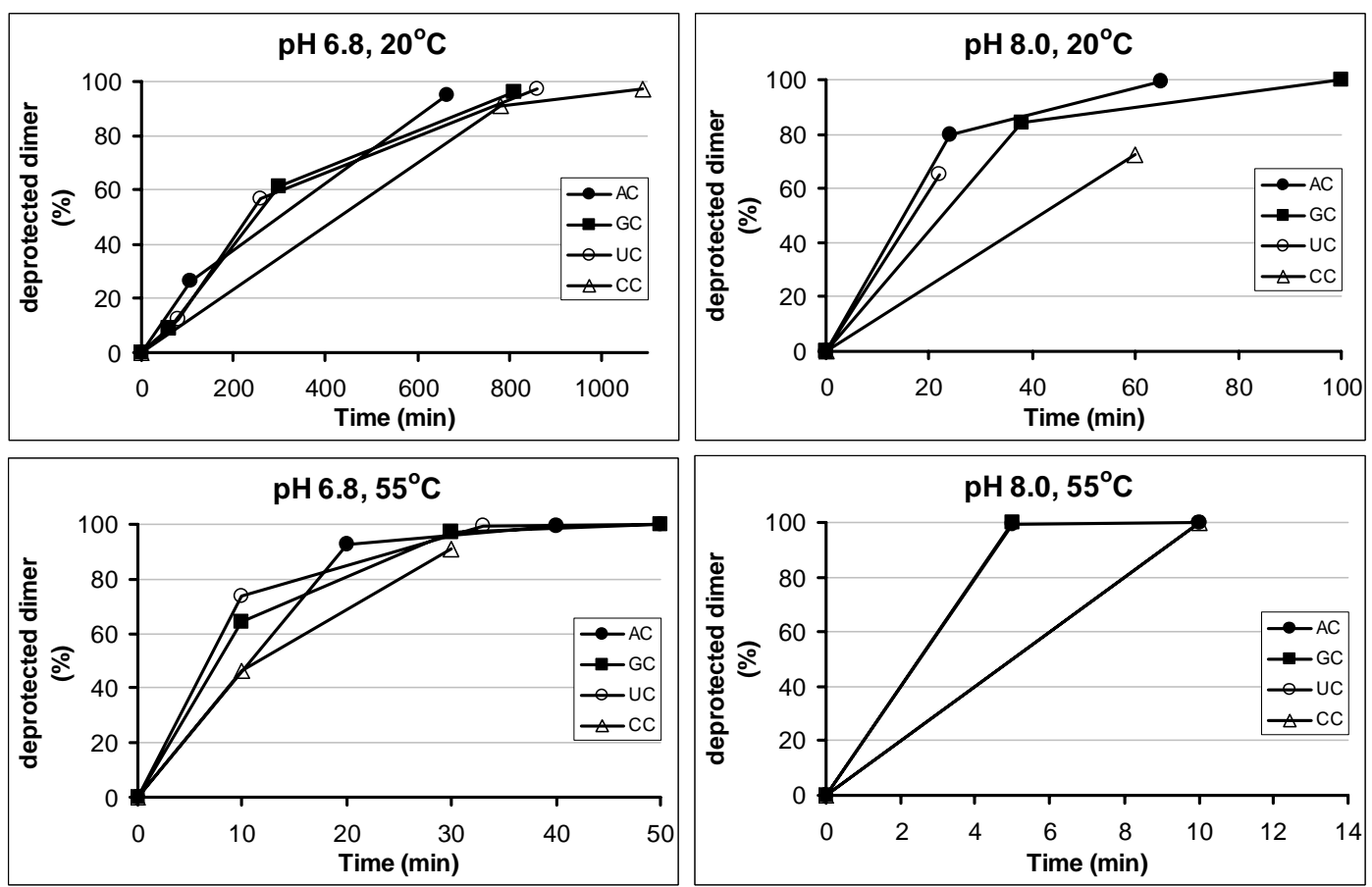

Supporting Information Figure 3. Deprotection rates of RNA dimers $(0.1 \mathrm{mM}$ in $0.2 \mathrm{M}$ phosphate buffer), having different 2'-O-DTM-protected nucleosides on their 5'-termini, upon treatment with DTT $(50 \mathrm{mM})$. Calculated from HPLC chromatograms. 

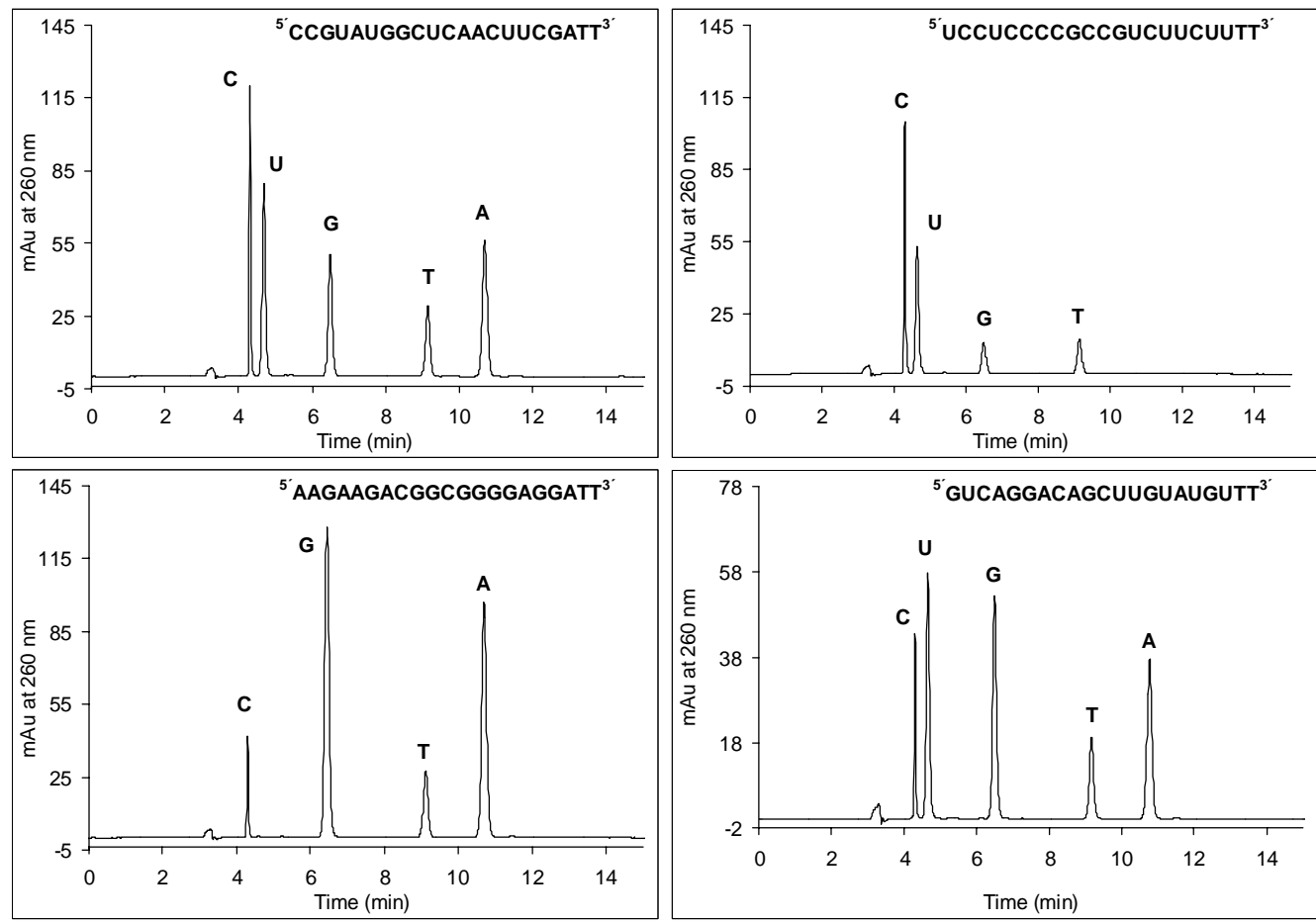

Supporting Information Figure 4. Nuclease P1 and alkaline phosphatase mediated hydrolysis of RNA synthesized by the DTM method. The oligonucleotides were mixed with $2 u$ of Nuclease $\mathrm{P} 1$ and incubated for $3 \mathrm{~h}$ at $37^{\circ} \mathrm{C}$. Then $14 \mathrm{ku}$ BAP was added, and the mixture was incubated for additional $3 \mathrm{~h}$ at $37^{\circ} \mathrm{C}$. The reactions were stopped with phenol:chisam extraction and precipitation in ethanol. HPLC: linear gradient from A to $7 \%$ B in $20 \mathrm{~min}$. 


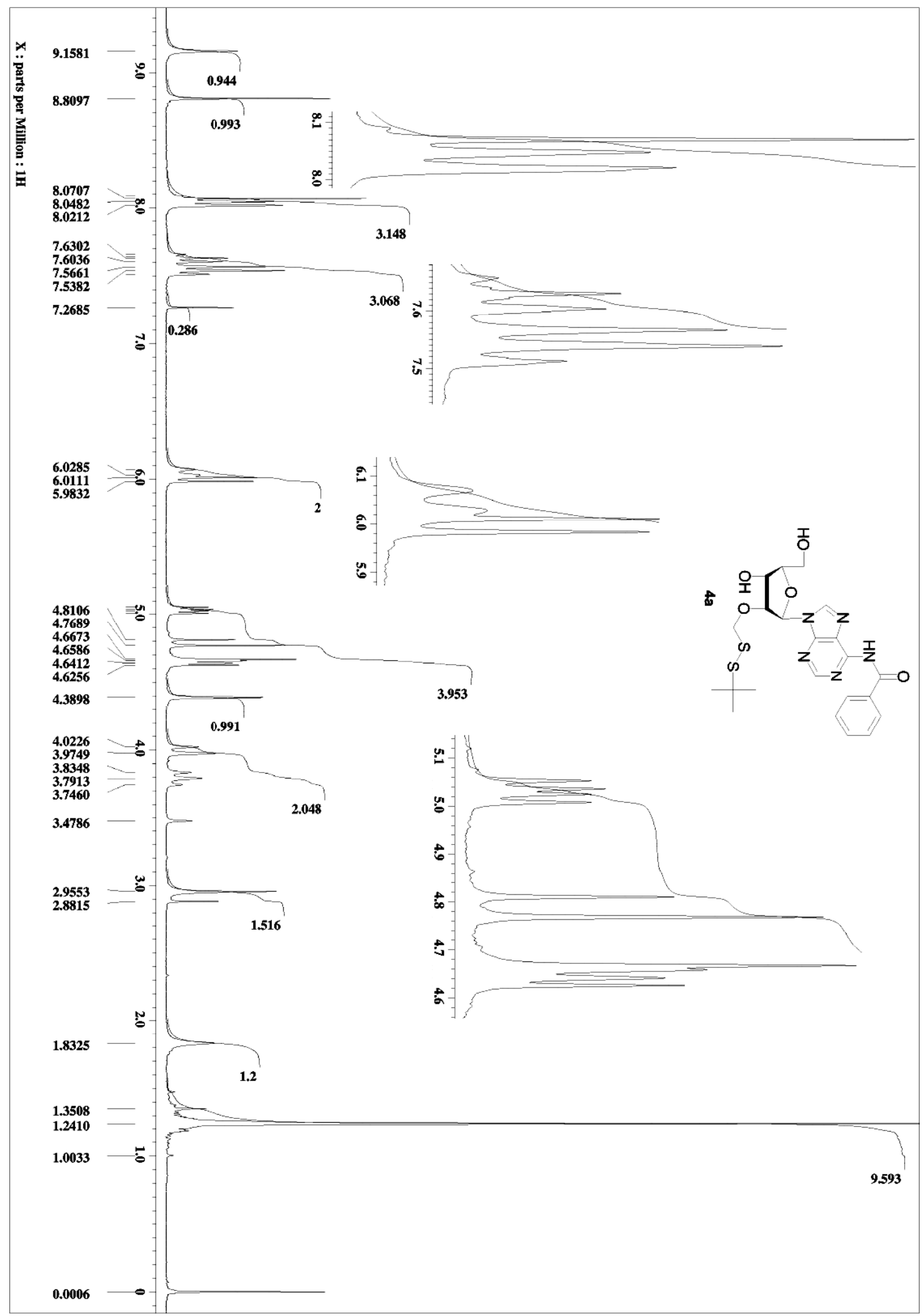




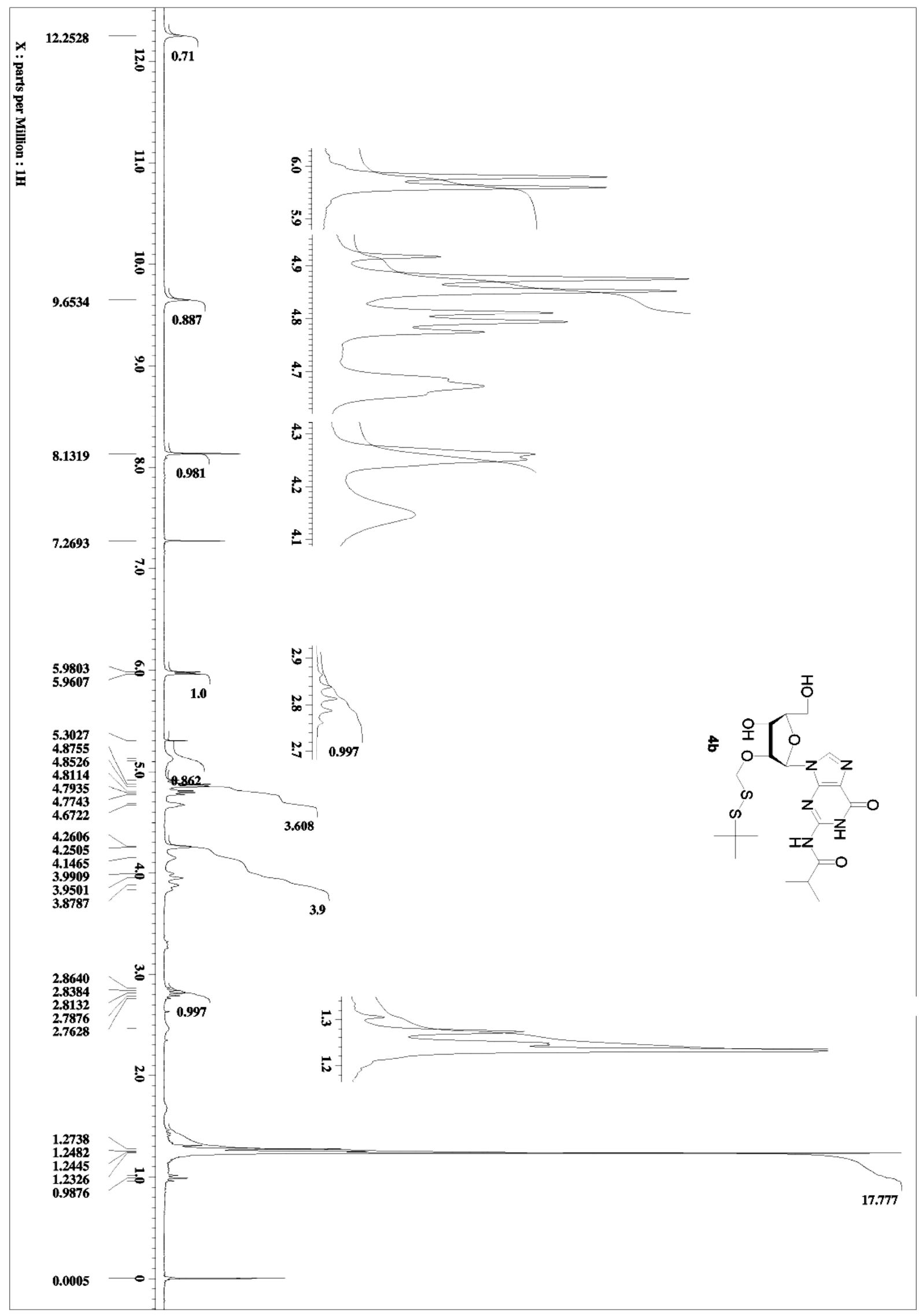




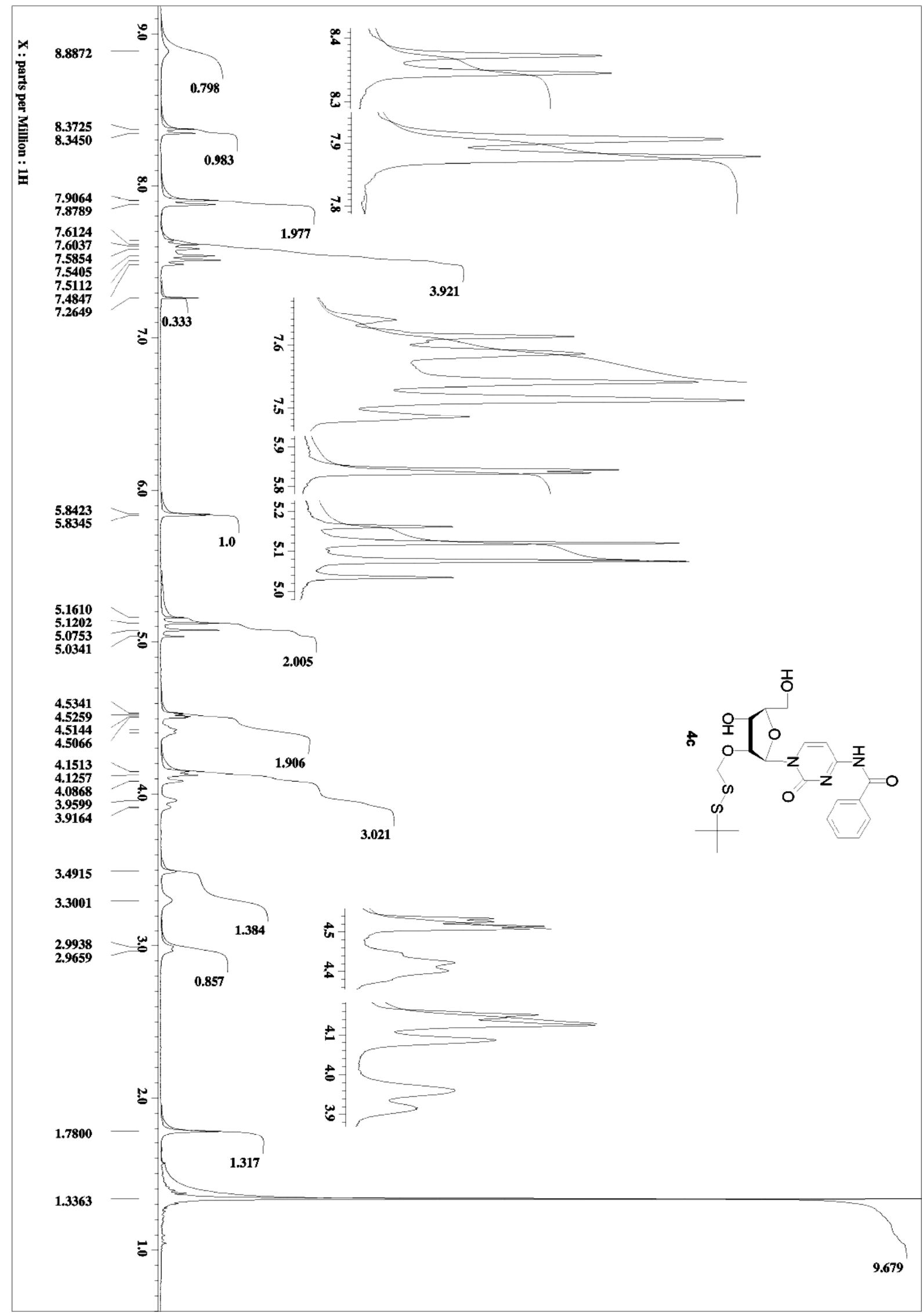




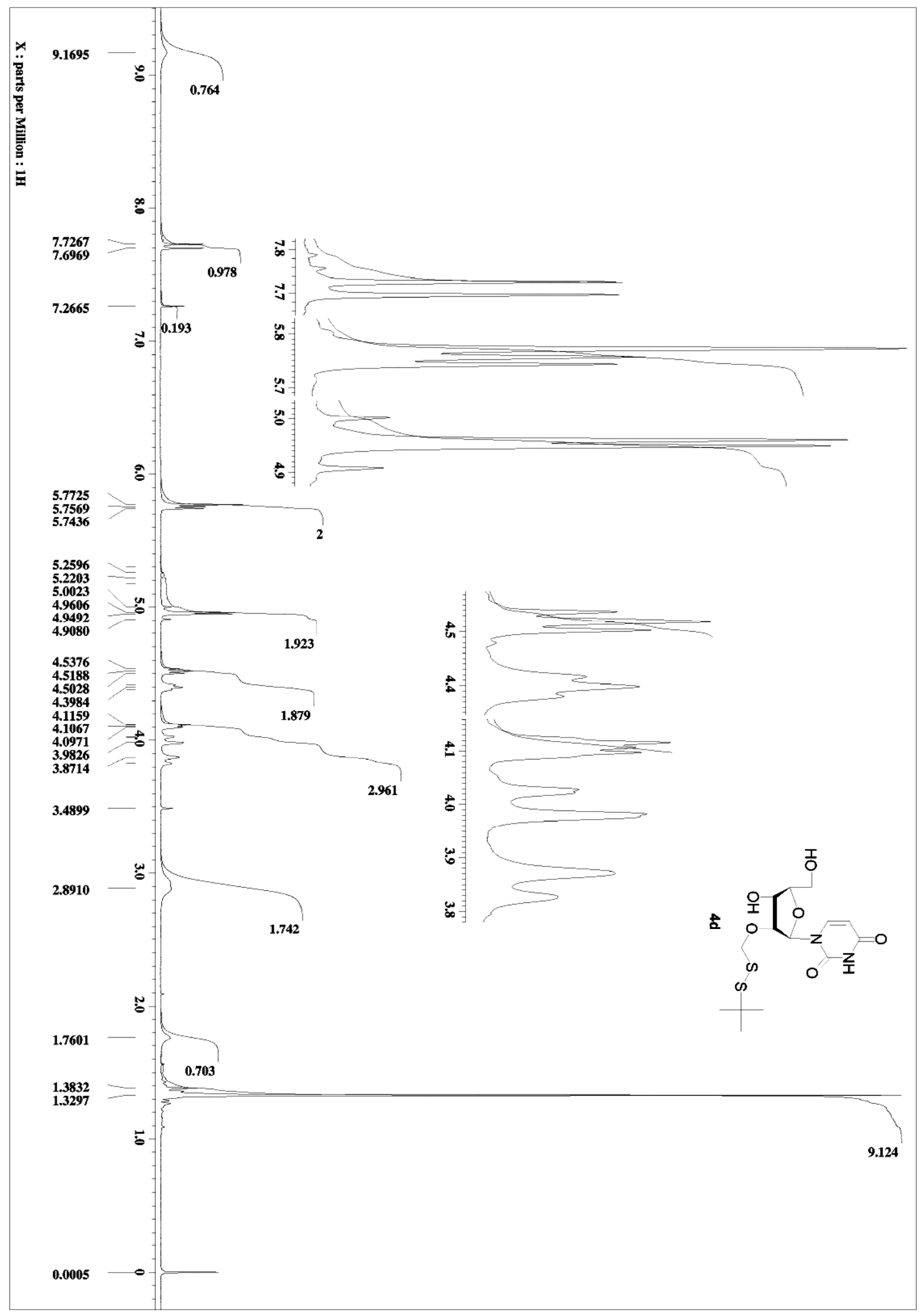




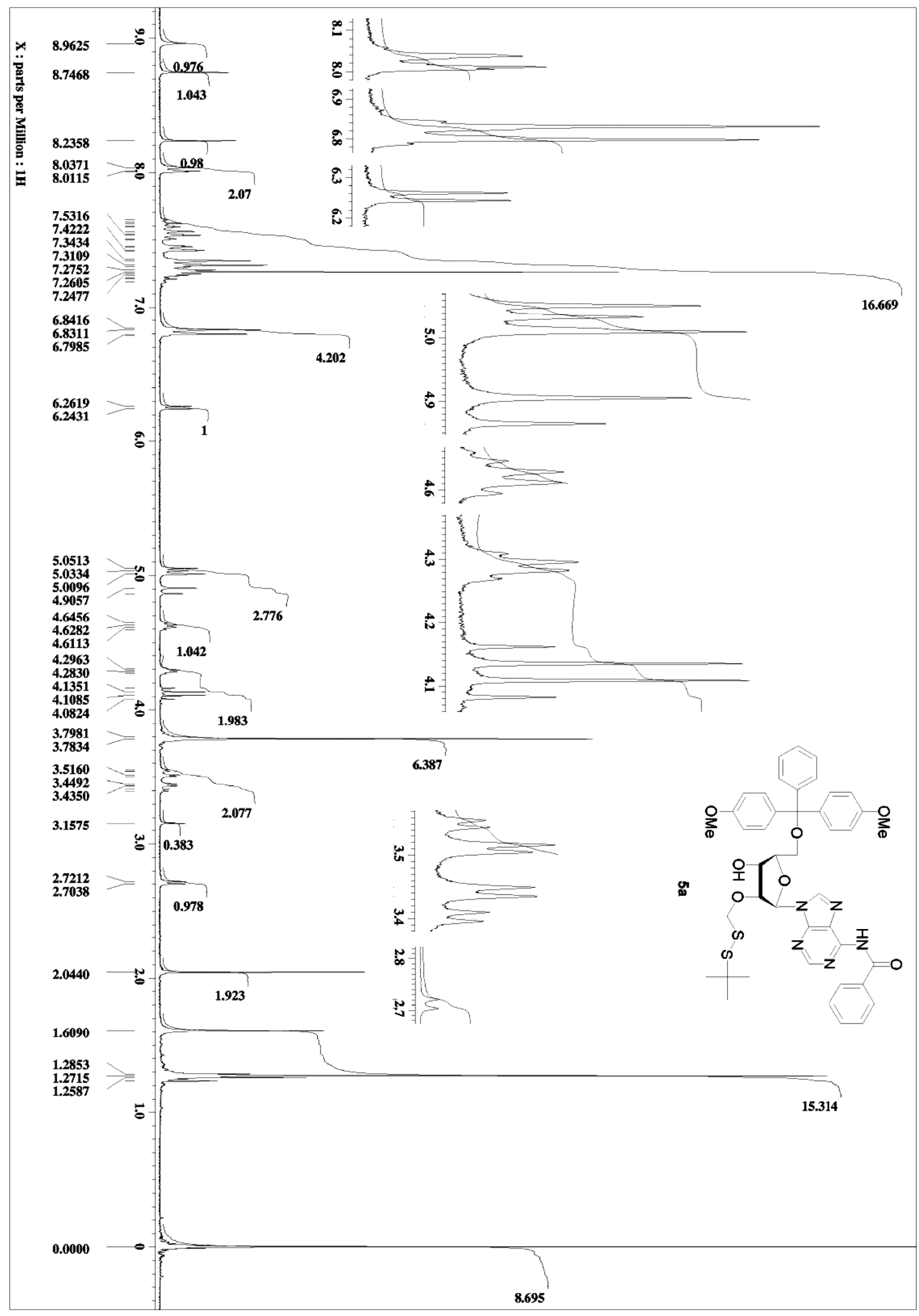




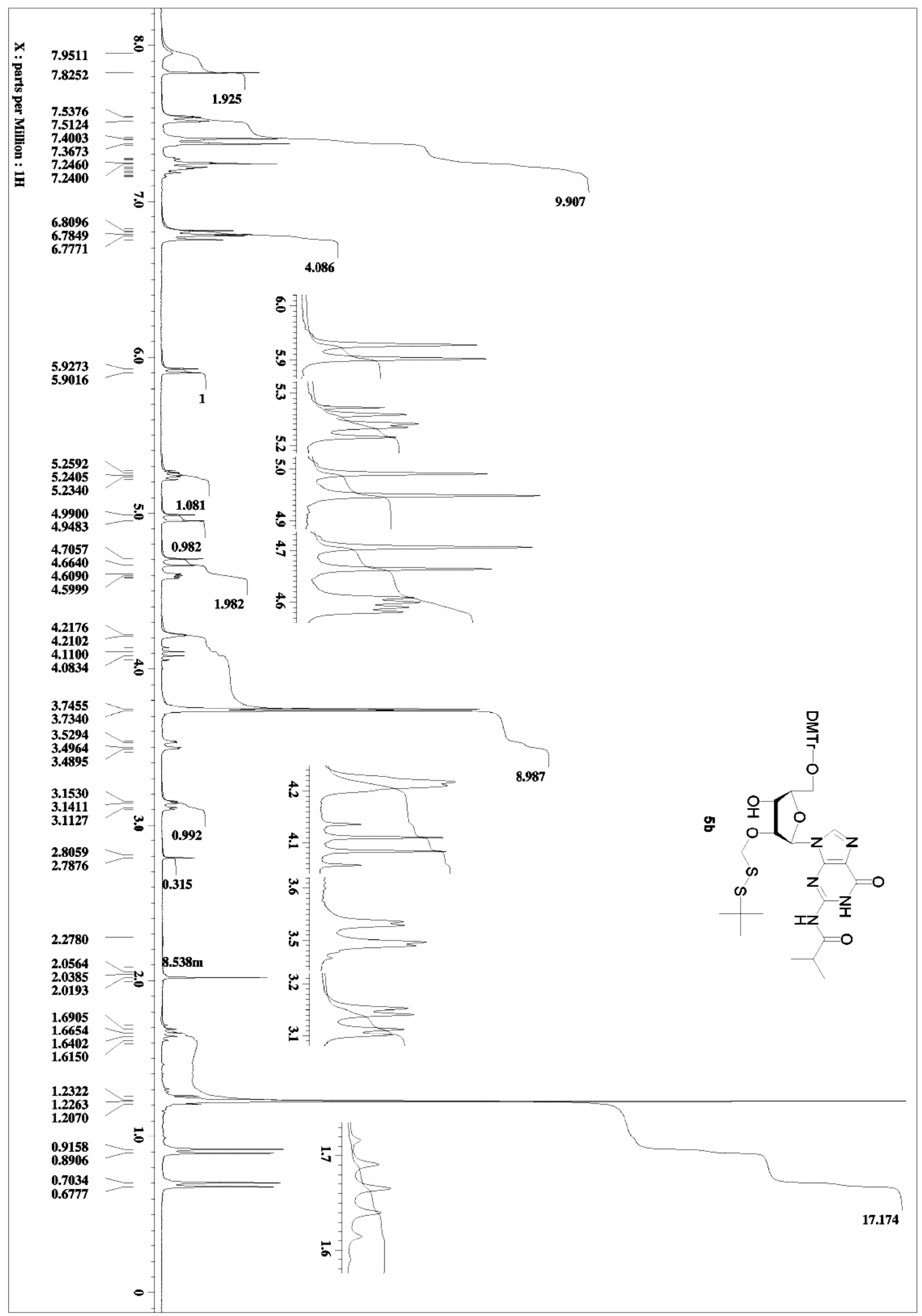




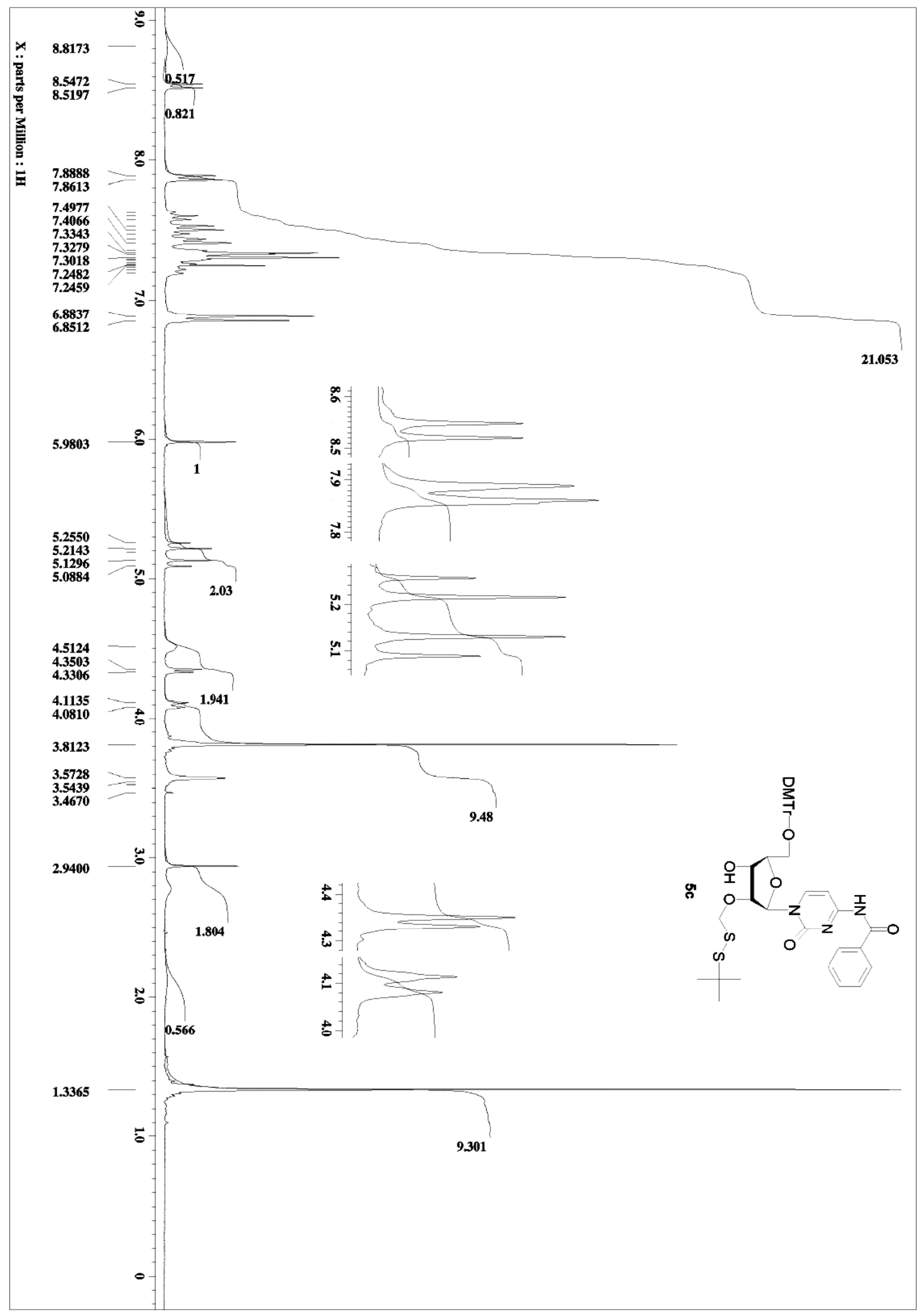




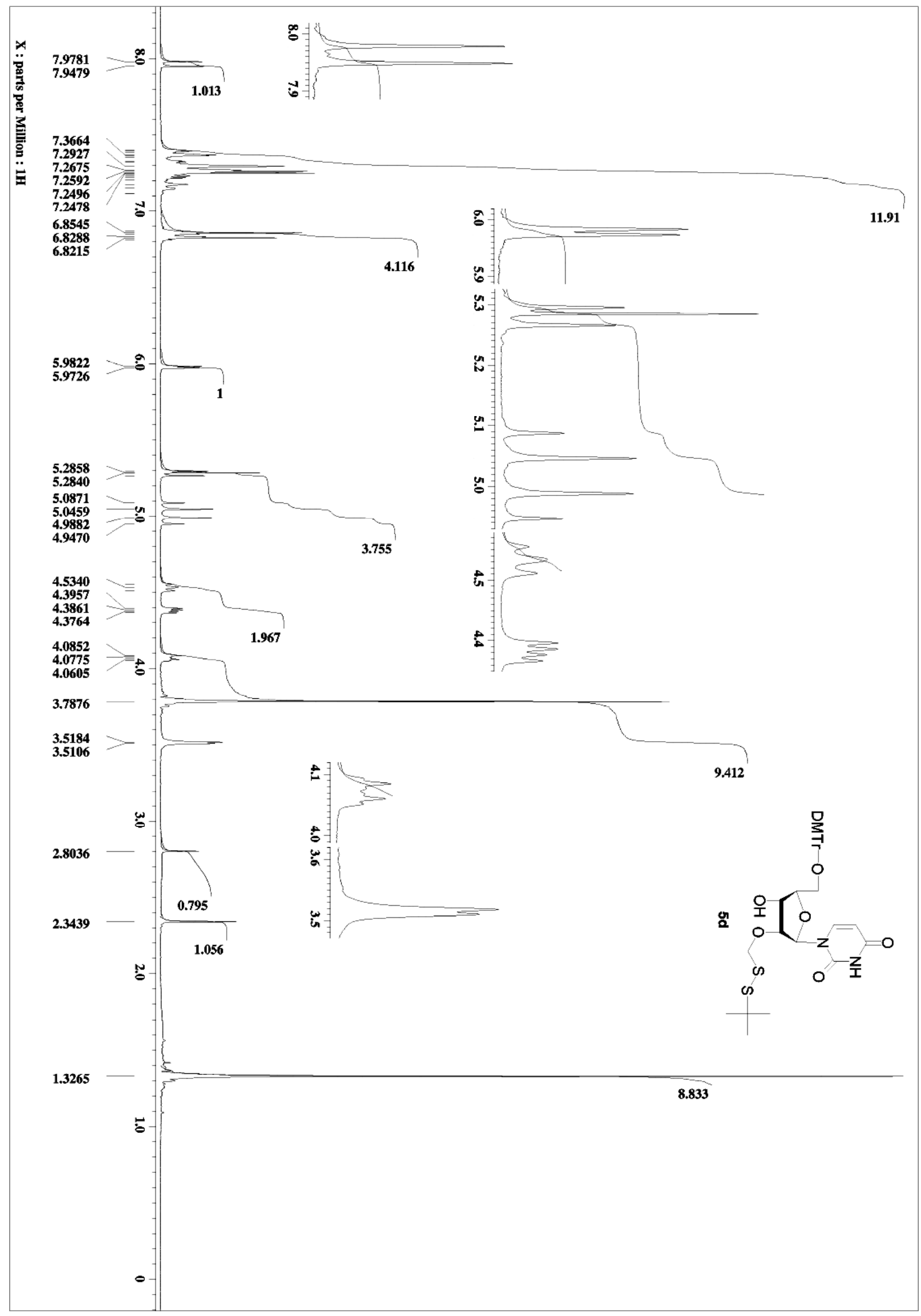




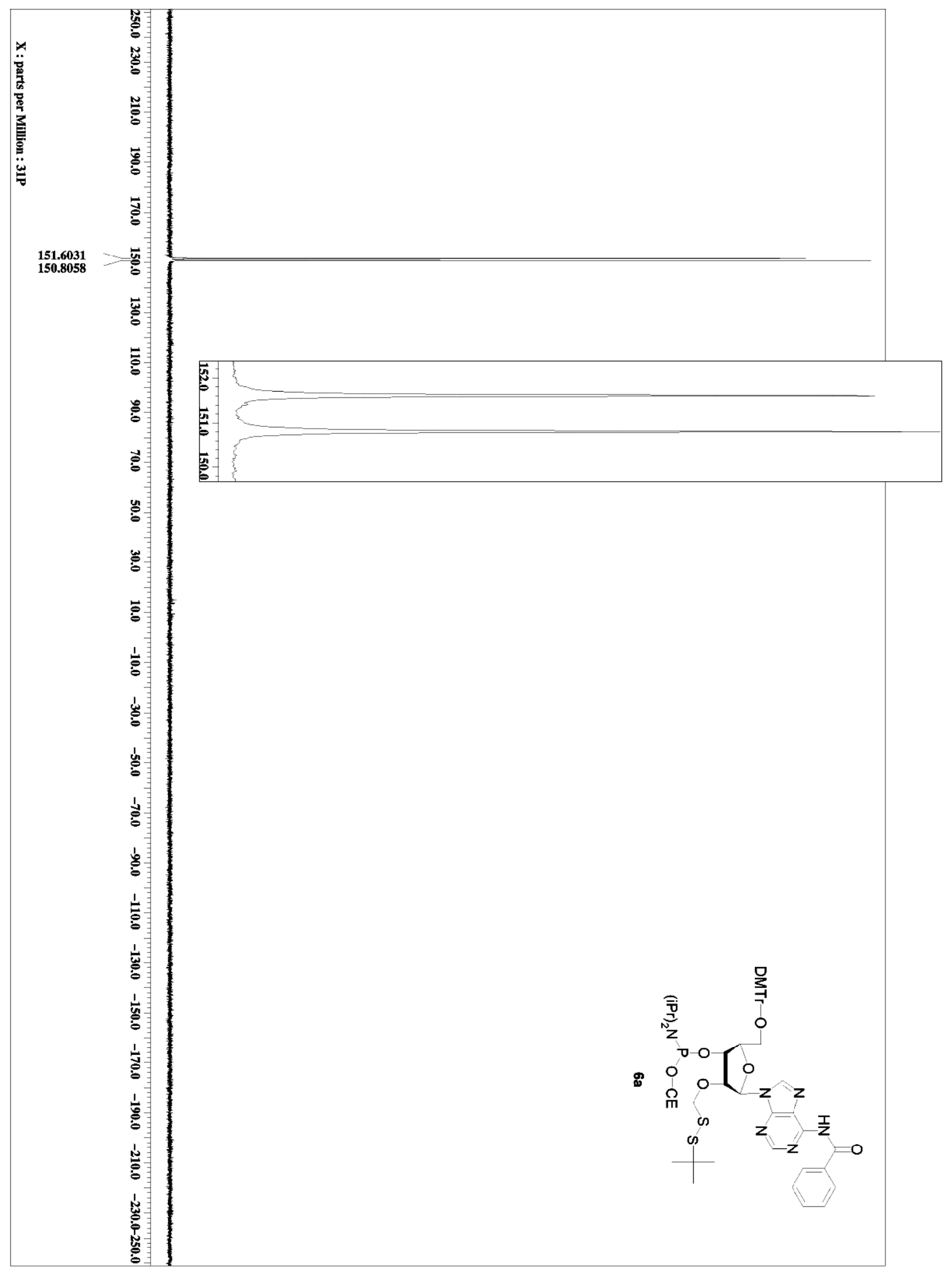




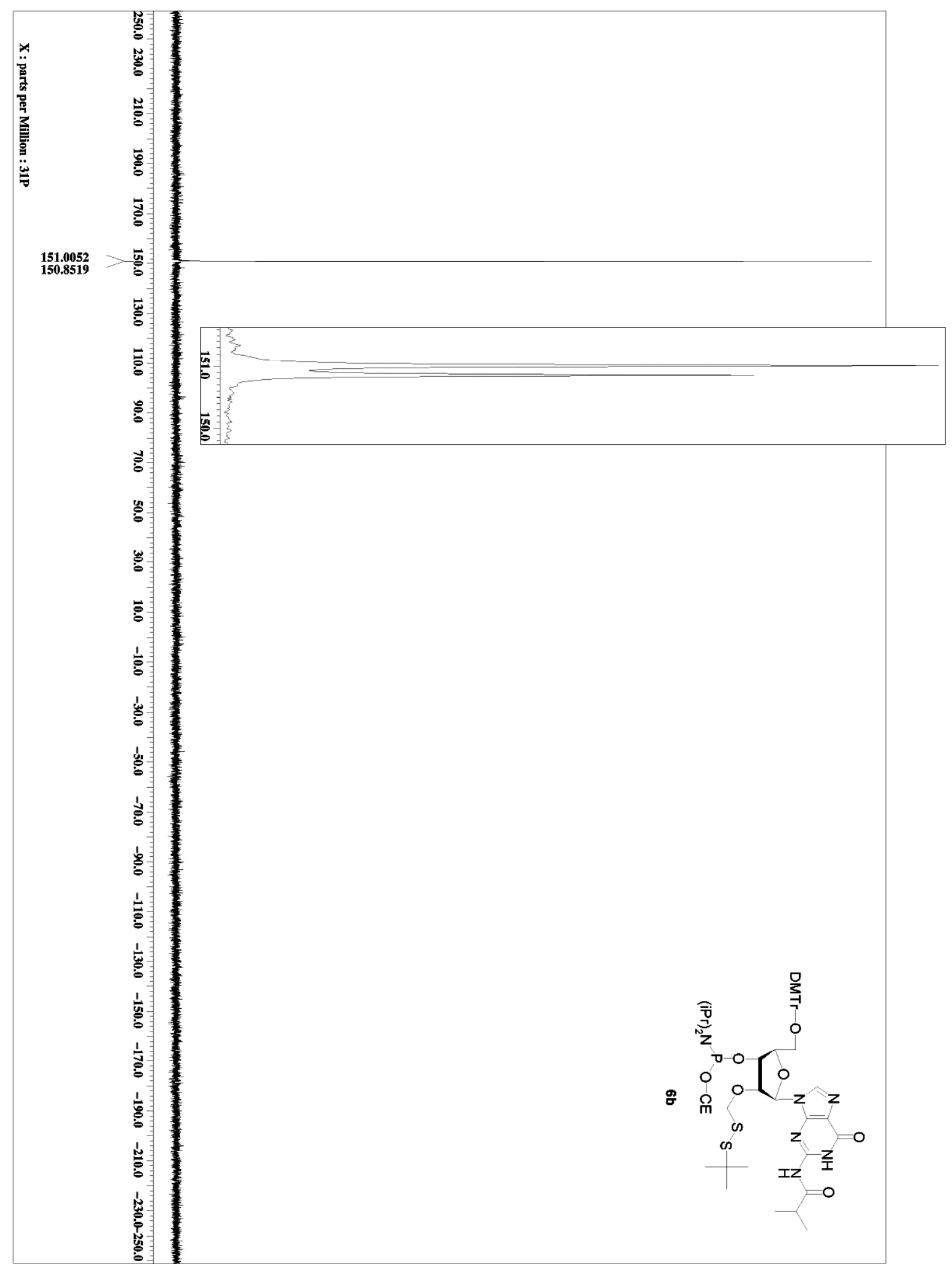




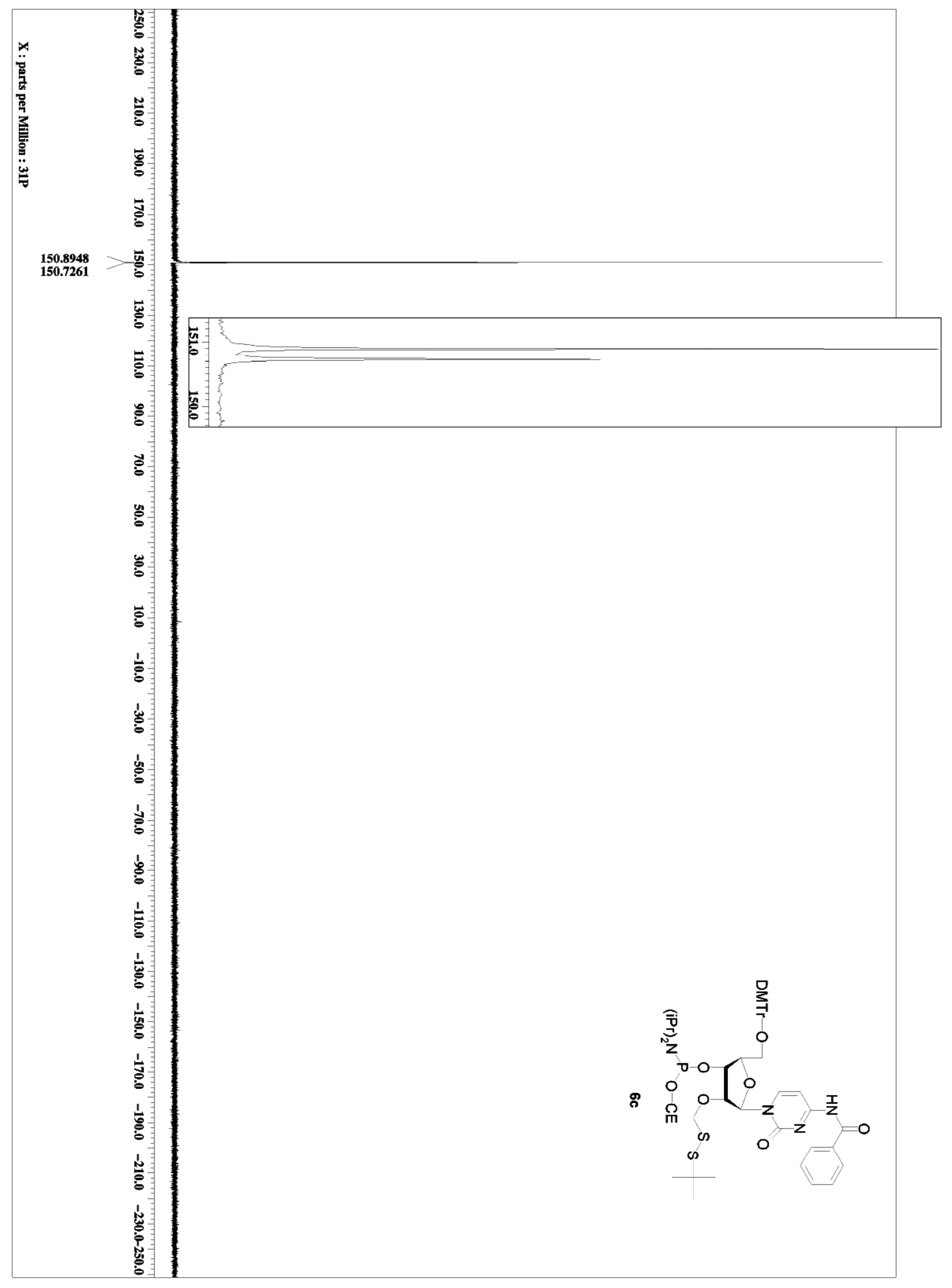




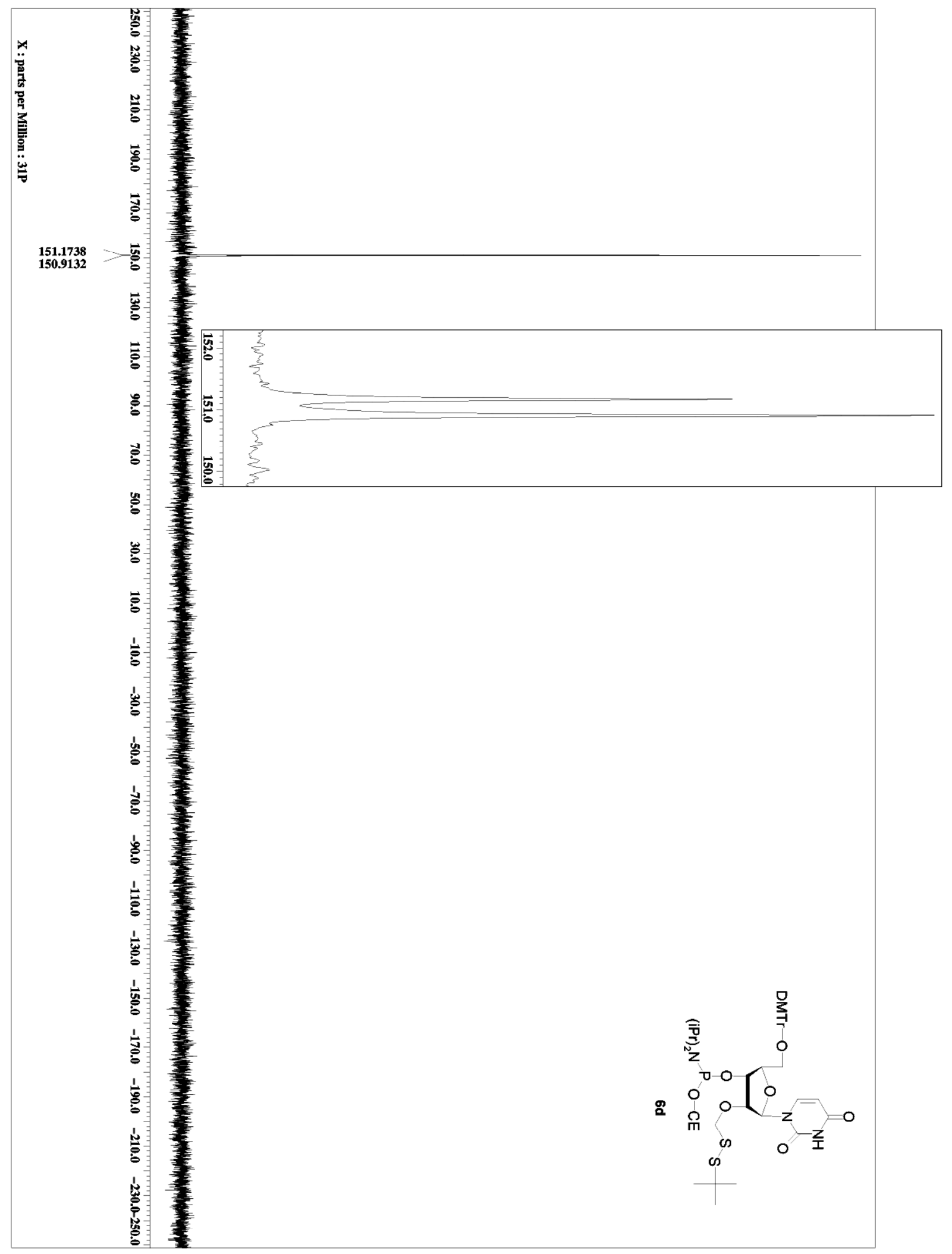




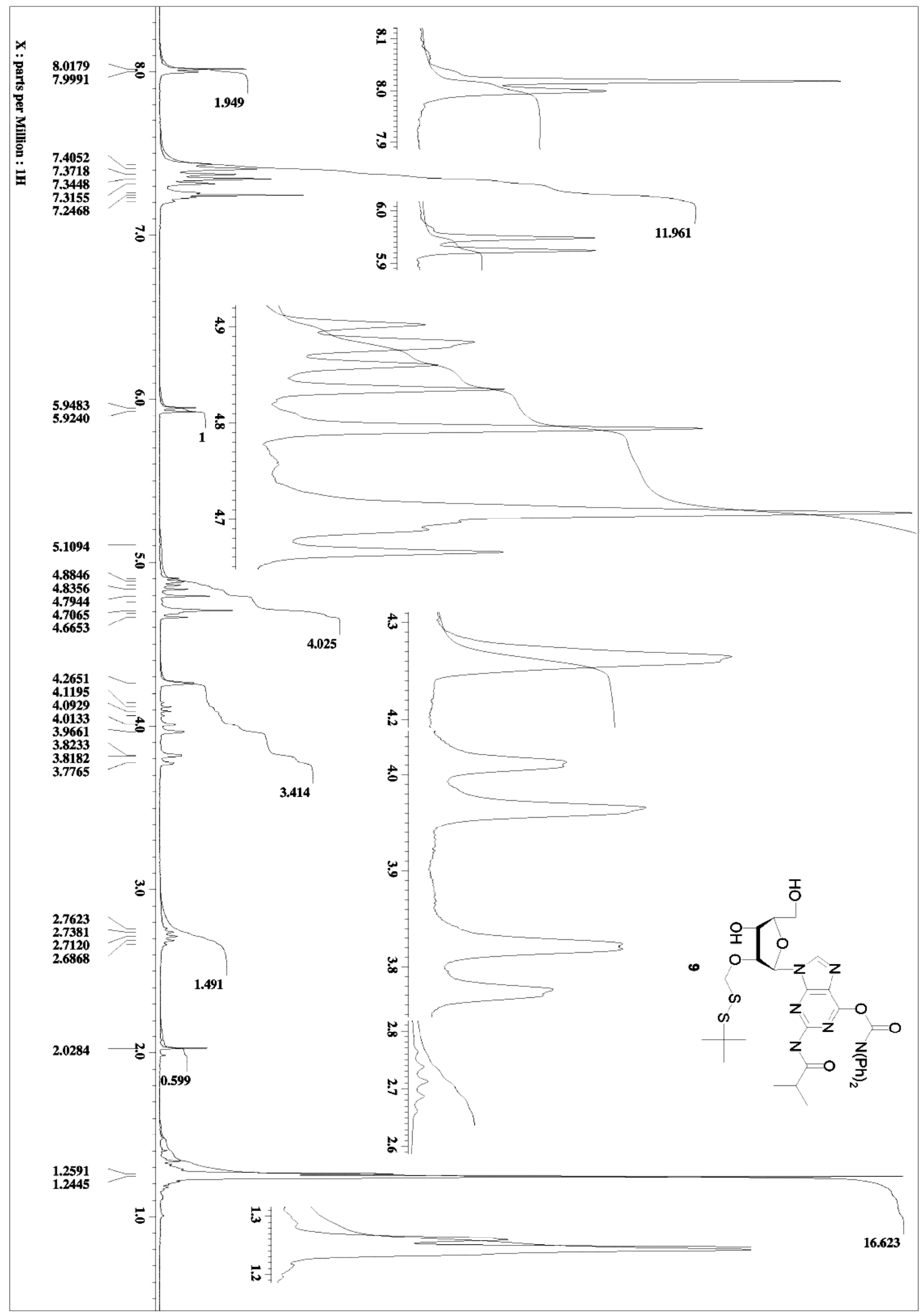




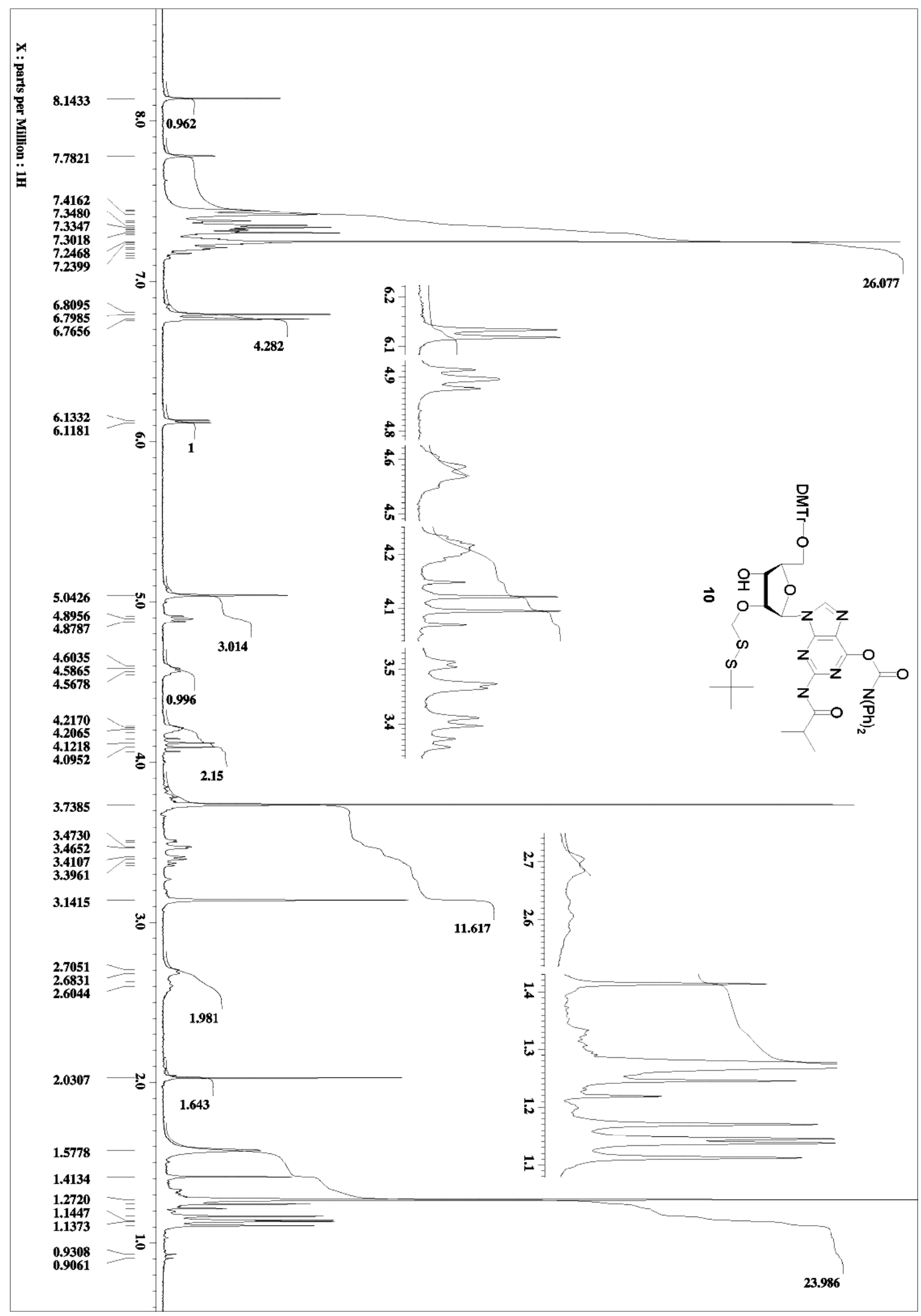




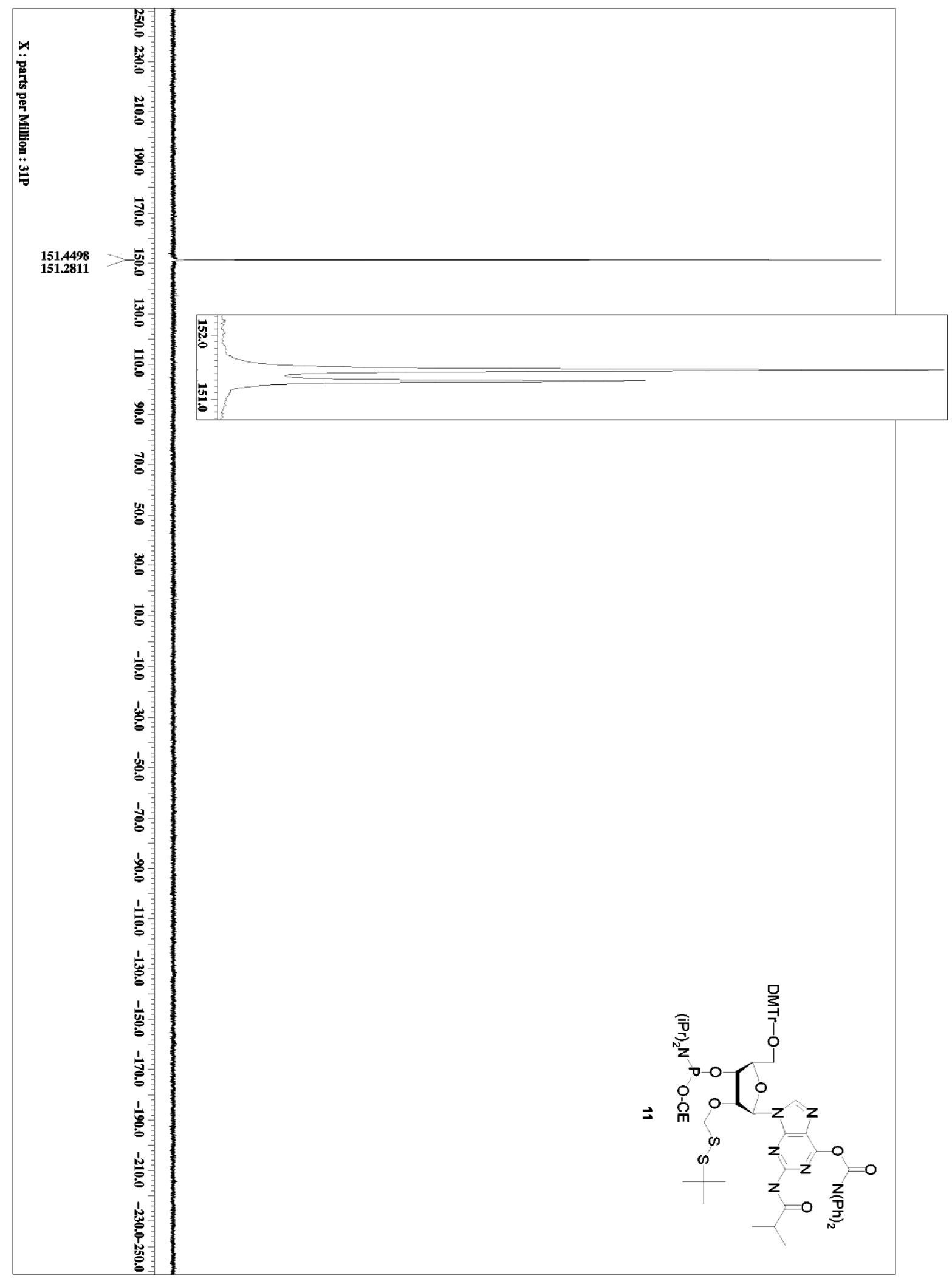

